\title{
Crossing Ethnic Barriers Enforced by the KGB: Kharkiv Writers' Lives in the 1960s-70s
}

\author{
Olga Bertelsen
}

Embry-Riddle Aeronautical University

\begin{abstract}
This study analyzes the foundations of unity developed by the Kharkiv multi-ethnic community of writers, and explores post-Khrushchev Kharkiv as a political space and a place of state violence aimed at combating Ukrainian nationalism and Zionism, two major targets in the 1960s-70s. Despite their various cultural and social backgrounds, the Kharkiv literati might be identified as a distinct bohemian group possessing shared aesthetic and political values that emerged as the result of de-Stalinization under Khrushchev. Archival documents, diaries, and memoirs suggest that the 1960s-70s was a period of intense covert KGB operations and "active measures" designed to disrupt a community of intellectuals and to fragment friendships, bonds, and support among Ukrainians, Russians, and Jews along ethnic lines. The history of the literati residing in Kharkiv in the 1960s-70s, their formal and informal practices and rituals, and their strategies of coping with state antisemitism, anti-Ukrainianism, terror, and waves of repression demonstrate that the immutability of ethnic barriers, often attributed to Ukrainian-Russian-Jewish encounters and systematically reinforced by the KGB, seems to be a myth and a stereotype. The writers negated them, escaping from and at the same time augmenting the politics of the place. Their spatial and social practices and habits helped them create a cohesive community grounded in shared history, shared interests in literature and dedication to it, and shared threats emanating from city politics and the KGB. They transcended ethnic boundaries constructed by the authorities, striving for unity, free from Soviet definitions.
\end{abstract}

Keywords: Kharkiv literati, multi-ethnic community, Ukrainian-Russian-Jewish encounters, state antisemitism.

\section{INTRODUCTION}

$\mathbf{O}$

ver the years, Kharkiv writers and patriots have published several collections of poetry and prose that include excerpts from works written by celebrities (Stadnychenko; Beliaev and Krasniashchikh). They offered comments about Kharkiv that largely conveyed a positive image of the city as a significant cultural and literary centre. Most of these writers happened to visit Kharkiv as tourists, reflecting their intimate experiences of the place and viewing it viscerally and often superficially. These reflections lack the discerning vision of Kharkiv's permanent residents informed by their experiences that for the most part were tragic, gloomy, 
and dangerous, especially during the Soviet era. For example, the former Kharkivite and writer Mykola Shatylov (b. 1939) remembered Kharkiv in temporal terms-"the cursed seventies" ("kliati simdesiati"). His predecessor Pavlo Tychyna (1891-1967) had doubts about Kharkiv's cultural pre-eminence, emphasizing its industrial prominence and its resemblance to the Donbas (Stadnychenko 37-38). Another Kharkivite and a historian, Volodymyr Kravchenko, has argued that the city's borderland history shaped its "middle way," where the epithets "remarkable" and "outstanding" seem out of place ("Kharkiv: A Borderland City" 221). In the 1960s-70s, the Communist Party and the Soviet Ukrainian authorities solidified Kharkiv's image as an industrial city rather than a cultural centre. For them, the cultural history of Kharkiv, the first capital of Soviet Ukraine, was a distant and possibly unknown past, and they promoted Kyiv as the epicentre of Ukraine's cultural development.

These views were shared by many Kharkiv literati who resided in the city in the 1960s-70s. They defined the place as an archetypally provincial backwater where culture was constrained and the political atmosphere was musty. Indeed, Kharkiv's political space was efficiently controlled by local Communist Party officials, and the Committee for State Security (KGB) ensured these practices. Despite Kharkiv's rich cultural traditions within the Russian empire and the cultural renaissance centred in Kharkiv during the early Soviet period (Sumtsov; Kravchenko, Khar'kov/Kharkiv; Zaitsev et al.; Leibfreid and Poliakova; Ploticher 18-34; Rakytians'ka; Bertelsen, "The House of Writers"), tensions between the cosmopolitan demographics of Kharkiv and Soviet politics, as well as the state's strategic plan for the city to be an industrial centre, obscured the luminosity of Soviet cultural Kharkiv.

This might be why most cultural historians turned their attention to Soviet Kyiv and Lviv, where the movement known as "shistdesiatnytstvo" encouraged by the 1960s generation (the "shistdesiatnyky") was particularly vibrant, valiant, and flamboyant (Bellezza; Amar; Risch; Yekelchyk; Tarnashyns'ka; Tromly). As a result of the spatial focus of this scholarship, most of the Kharkiv writers mentioned in this essay are unfamiliar to wellinformed readers and scholars of Ukraine's twentieth-century literature, as are the developments in Kharkiv pertaining to the most important scholarly discourses, such as state violence and multi-ethnic cross-cultural dialogues in twentieth-century Ukraine.

In the 1960s-70s, persecution of writers, and several waves of repression targeting Ukraine's intellectuals, coincided with re-Stalinization, visible at all levels-social, cultural, and political. According to KGB reports, the conversion of Kharkiv writers into a cogent cohort of Soviet writers who were supposed to help the Communist Party build one Soviet nation by bringing culture to the masses was not going well. Drunk with the freedom allowed by the Khrushchev Thaw that lasted from 1956 to 1963, the writers 
wrote what they were not supposed to write, gathered where they were not supposed to gather, and spoke non-Soviet (paraphrasing Stephen Kotkin's metaphor [220, 221-25]) in literary clubs that mushroomed in Kharkiv after the late 1950s. ${ }^{1}$ They organized themselves on a basis of shared aesthetic interests and political views, and began to express themselves in ethnocultural terms. They established inter-ethnic alliances and bonds, a serious concern for the KGB whose members designed a set of "active measures" to disband congregations of the writers and to compromise the friendships that began to form within the Writers' Union, and in formal and informal multicultural literary clubs. ${ }^{2}$ According to KGB professionals, cultural Kharkiv presented a complex and dangerous network of connections among literati, artists, and actors that transcended ethnic boundaries. These inter-ethnic bonds ultimately negated ethnic barriers covertly erected by KGB operatives during their "prophylactic" private talks with the writers. In the KGB's analyses, the desired ideological and propaganda flair began to disappear from Kharkiv prose, poetry, and art. Instead, romantic, intimate, national, and ethnically patriotic motifs emerged, a phenomenon that was inconsistent with the notions of undeviating fidelity to Communist doctrines demanded by the party. As one Kharkiv party leader stated in the 1960s, "it seems quixotic-there is too much of Shevchenko in the writers' and artists' works; it obscures the Leninist international principles of art" (interview with Briuhhen, 16 July 2015; Iarova). ${ }^{3}$

Despite the pressure on editors of Kharkiv literary journals and newspapers, many of them defended the writers' innovative approaches, publishing prose and poetry that were seditious in the KGB's view. They shared the writers' enthusiasm associated with liberal changes launched by Khrushchev, and their quest for moral and intellectual refinement. A shared desire for freedom, amplified by the threat of imprisonment as punishment for their failure to reconcile their creative work with propaganda, served as the foundation for new rapprochement among Ukrainians, Jews, and Russians in the Writers' Union and informal literary groups.

\footnotetext{
${ }^{1}$ For an analysis of political changes in the USSR and Ukraine during the Khrushchev Thaw and its rollback, see Viktor Danylenko.

${ }^{2}$ Similar tendencies could be observed in other Soviet republics, including the RSFSR (Plokhy, Lost Kingdom 290-94). "Active measures" (or ideological subversion) is a KGB term that emerged in the early 1950s and implied domestic actions and transnational special operations designed to change the oppositionists' and the rivals' ideology, their perception of reality, and ultimately the course of world events to the advantage of the USSR (Schuman).

3 Unless otherwise stated, all translations in this article are mine.
} 
The shared history of Ukrainians, Jews, and Russians, their inter-ethnic relations, and the birth of new identities in Ukraine have been examined by many scholars. ${ }^{4}$ There is a consensus among historians that, in a variety of ways, the Soviet regime exacerbated the hostilities between Ukrainians and Jews that went back to the seventeenth century (Kuzio, Putin's War against Ukraine 118-26; Zeltser; Liber; Plokhy, Unmaking Imperial Russia, and The Gates of Europe 296; Kappeler 52-55; Benifand; Motyl 15; Conquest 83-84). Thus, the rapprochement and the multi-ethnic cross-cultural dialogues that occurred at the most tragic crossroads in Ukraine's twentieth-century history have been thorny. For example, World War II brought charges of antisemitism and anti-Ukrainianism to the forefront of many scholarly and public discussions in Ukraine and beyond (Snyder, Bloodlands, and Black Earth; Himka "Interventions," "The Lviv Pogrom of 1941," and "Ukrainian Memories of the Holocaust"; Radchenko, "'We Fired All Cartridges at Them,"” "Ukrainian Historiography," and "The Organization of Ukrainian Nationalists"). Moreover, the chaos and inconsistencies of the Soviet era produced paradoxes associated not so much with dual or multiple identities (which is a temporally and spatially universal phenomenon), but rather with unsubstantiated super self-confidence combined with confused mutually exclusive identities: internationalists behaved like antisemites, racists advocated equality, nationalists rejected other nationalisms, and intellectually shallow bureaucrats who wrote their reports with grammatical errors genuinely believed they were in a position to educate brilliantly talented and highly educated intellectuals and writers and teach them learning and writing skills.

The KGB took advantage of these oddities, covertly playing all sides against each other and creating a space and rhetorical support for ethnic and racial hatred. This strategy was supposed to perpetuate ideological confusion and help control unruly nationalists in the republics and beyond the borders of the USSR. With the exception of a few, the Kharkiv writers refused to be persuaded by the KGB and refused to hate. The aesthetics of the Kharkiv literati, a multi-ethnic community of men and women of several generational cohorts, superseded the politics of the place. A culturally diverse group, Kharkiv writers nevertheless strove for freedom and unity, turning a deaf ear to KGB officers' antisemitic remarks and disregarding their diagnostic tests for nationalism or latent antisemitism. They saw these

4 See Shtif; Bartov; Gilley; Magocsi and Petrovsky-Shtern; Bilenky, Romantic Nationalism 253-302, and Imperial Urbanism; Dekel-Chen; Fowler; Shanes and Petrovsky-Shtern; Hunczak; Snyder, Sketches from a Secret War; Prusin; von Hagen; Petrovsky-Shtern, "Reconceptualizing the Alien," "Jews in Ukrainian Thought," The Anti-Imperial Choice, "The Art of Shifting Contexts"; Redlich; Abramson; Bartal and Polonsky; Aster and Potichnyj. 
activities as provocations designed to divide and control the privileged members of the Writers' Union. Overdosed by fear, violence, and traumatic memories of World War II, writers of various ethnic origins tried to create not a Jewish, a Ukrainian, or a Russian street or neighbourhood but a multiethnic street, where everyone would be part of a shared but intimate experience, the experience of writing. ${ }^{5}$ The entire "neighbourhood" became a conceptual place for them where they acquired the strength and courage to continue.

Thanks to archival documents and Kharkiv writers' diaries, interviews, memoirs, and personal documentation, we are privileged to catch a glimpse of their relationships and to savour their experiences in Kharkiv in the 1960s-70s that would otherwise have disappeared from the multi-ethnic cultural history of Ukraine. ${ }^{6}$ Importantly, these experiences, which included the entire spectrum of human emotions, feelings, and mental stateshappiness, demoralization, disenchantment, fear, and love-were shaped by the place and the political and social realities of the time, as well as by its history. This spatial study offers an analysis of the patterns of human behaviour and socialization among Kharkiv literati-ethnic Ukrainians, Russians, and Jews - and their relationships and grounds for interaction in a space of violence and intellectual abuse. The inter-ethnic bonds they cultivated and the complex network of professional and intimate connections they established in Soviet Ukraine stayed alive for decades, often disrupted by geography and disagreements but reviving each time the opportunity presented itself. An analysis of the Kharkiv writers' interactions with the Kharkiv authorities and the KGB, and the writers' practices, rituals, and views will help illustrate this point.

\footnotetext{
${ }^{5}$ On the notions of intimate or shared experience and neighbourhood, see Tuan 16971.

${ }^{6}$ This essay is not a literary study and does not closely analyze Ukrainian and Russian works published in Kharkiv under Khrushchev and Brezhnev. Neither does it discuss Jewish work in literatures other than Jewish (in this case in Ukrainian and Russian literature, as Kharkiv was and remains a bilingual city), an approach that Vladimir Zhabotinskii (Zeev) (1880-1940) found predominantly fruitless and humiliating for Jews because of their forcible acculturation that cultivated slave psychology and encouraged them to abandon interests in Jewish affairs and culture. Nor is this a case study, but rather an overview of space and place, the Kharkiv of late socialism, saturated with optimism, hope, sorrow, and frustration.
} 


\section{KHARKIV WRITERS' AMBIVALENCE TOWARD KHARKIV}

Marcel Proust's novel À la recherche du temps perdu (Remembrance of Things Past, 1981) demonstrates that people and places intermingle in a variety of ways. $^{7}$ Places capture and shape people's imaginations and keep their memories alive. Kharkiv of the 1960s-70s was a space of "controlled freedom," using Ievhen Sverstiuk's term, and, on a number of occasions, it became the epicentre of KGB special investigations and interest. Petro Shelest, Ukraine's Communist Party leader, systematically alerted the local authorities about professors' seditious thinking at Kharkiv Karazin State University, detailing the writers' "ideologically harmful" congregations and drunken parties, as well as foreign citizens' interest in objects of military and strategic importance located in Kharkiv during their tourist trips (Bertelsen, "Political Affinities" 400; TsDAHOU, 1/25/17/36-37, 42-49; 1/25/387/2123; HDA SBU, 16/1/1017/6-8; 16/1/1064/10). Shelest insisted that, considering the importance of Kharkiv to the USSR's national security, the ideological work among the nationally conscious intelligentsia and the KGB's intelligence service should be amplified and improved. He asked Moscow to increase the quotas of KGB personnel and to create more KGB departments in Kharkiv to cope with the challenges (TsDAHOU, 1/25/387/21-23). In May 1971 , on the eve of the second wave of repression against the intelligentsia, Ukraine's KGB chief Vitalii Fedorchuk established two additional positions in Kharkiv and Kyiv-deputy heads of KGB Oblasts' Administrations, and increased the number of KGB officers working in these localities (HDA SBU, $16 / 1 / 1017 / 182)$. For Kharkiv writers, these developments meant that their activities and habits had to be changed, and their creative work must be refocused in tune with Communist Party orders and the renewed Stalinization of Kharkiv. In their memories, the Kharkiv of Khrushchev and Brezhnev remained not simply a "sum of streets and houses" that they tenderly remembered as places of gathering and youth, but a centre of meaning, associated with shared experiences of state violence and national humiliation (interview with Tret'iakova, 19 July 2005; Kotliarov; Vysheslavskii). ${ }^{8}$ Like Marcel, the narrator in Proust's novel, who inevitably returned intellectually and physically to the place of his youth, Kharkivites who lived through this period persistently followed this path, ruminating about the pleasure and pain Soviet Kharkiv gave them, and writing about the

\footnotetext{
7 Proust's novel in seven volumes was first published in France between 1913 and 1927. For a discussion about space, place, and people in Proust's writings, see Poulet 19-33; Malpas 4-5.

8 The names of Moscow party leaders and of writers who wrote in Russian or who resided in the Russian Federation have been transliterated from the Russian language (i.e. Mikhail Suslov, Boris Chichibabin, Anatolii Brusilovskii).
} 
city in an attempt to grasp the meaning of their past, present, and, ultimately, their future.

This desire to decode Kharkiv and their ambivalence toward the city came to some of the "shistdesiatnyky" decades later, when the spatial distance between their past and present was substantial. Many wandered away from the city in the 1960s-70s, seeking freedom and fame, which provincial Kharkiv, hijacked by the antisemitic Communist Party and KGB leaders, could not offer (Lahoza 95-96; private correspondence with Briuhhen, 2010-18). Many dreamed about escaping to Israel, Moscow, or Kyiv, anywhere to prevent decomposition of their vulnerable and subtle talent, and "excited and tender souls" (Brusilovskii 198; private correspondence with Brusilovskii, 1 Sep. 2017). But many stayed, providing Kharkiv with a certain distinctiveness through their cultural practices. ${ }^{9}$

In spite of their Kharkiv "topophilia," the dominating force pushing intellectuals away from the city was the choking atmosphere created by the local authorities. ${ }^{10}$ The leadership of the Kharkiv Writers' Union was part of the nomenklatura of Ukraine's Central Committee, presenting Kharkiv party bosses and the KGB "ample room for interference" (Goble 136). Constant threats and intimidation by the KGB and the local party organs disillusioned a great many of the intellectuals (Bertelsen, "Shistdesiatnyky"). The KGB personnel closely co-operated with the secretary of the Kharkiv oblast party committee ("obkom") Andrii Skaba (1905-86), a faithful Stalinist and an antisemite who supervised ideological work in Kharkiv. ${ }^{11}$ In their dialogue with the Kharkiv intelligentsia, away from the centre's eyes, many Kharkiv KGB operatives behaved frivolously and cruelly, often violating professional ethics and being reprimanded and fired for that by their Kyiv supervisors (HDA SBU, 16/1/1060/135-139; Kasha). The writers' telephones were tapped and their private conversations were thoroughly analyzed (HDA SBU, 16/1/1028/237). Their texts were carefully censored and extensively "castrated," as the Kharkiv poet Boris Chichibabin (Polushin) (1923-94) characterized his own volumes of poetry published in the 1950s-60s

9 On "imagined places" and their perceived cultural essence and practices, see Bilenky, Imperial Urbanism, and Romantic Nationalism; Berezhnaya; Ther; Kravchenko, Khar'kov/Kharkiv; Wolff; Richardson; Reid.

${ }^{10}$ For a discussion about "topophilia," the love of a place, see Bachelard.

11 Skaba kept this position until 1959 when he left for Kyiv, being promoted to the position of ideological chief of the Central Committee of the Communist Party of Ukraine (1959-68). On Skaba's attitudes toward Jews and his antisemitism, see Rakhlin 95-98. Skaba's infamous statement "We rehabilitated people, but not their ideas" fully reflects his ideological and political stance that shaped his activities in Kharkiv and later in Kyiv (Taniuk). For the tendency to exercise greater control over non-Russian writers in the Soviet republics (other than the Russian SFSR), see Goble. 
(Rakhlin 4,65). Poets made inscriptions on their newest volumes of poems, burning from shame and humiliation, and apologizing to their friends and colleagues for their content. Prophylactic talks between writers and officials in the Kharkiv "obkom" or the KGB inevitably ended up with the official suggesting that the writer watch for "those cunning Jews" or "nationalistic khokhly" (interview with Briuhhen, 2 July 2011). ${ }^{12}$

There existed, however, uncensored and brilliant literature in Kharkiv written mostly in Ukrainian and Russian. It lived its own life in unpublished manuscripts and samizdat formats ("samvydav" in Ukrainian), betraying its authors in the eyes of the KGB, if found, and simultaneously immortalizing them. In this sense, Kharkiv writers were an inseparable part of a cultural movement in the early 1960s. This was not a political movement but rather a rebellion against the mediocracy that the Soviet regime cultivated over the years. Interestingly, observing these cultural and literary trends in the Soviet Union, CIA analysts emphasized in their reports the boldness of old and young writers who "came into open conflict with the dictates of political orthodoxy." They wrote: "Soviet writers have demonstrated a measure of personal integrity and unity of purpose unmatched by any other segment of Soviet society" (CIA Archive, "The Soviet Writer and Soviet Cultural Policy," i). This was also true for a diverse and multi-ethnic community of the Kharkiv literati, for whom the only space where they could exercise power was the space of creative writing (DAKhO, R-6165/1/148/22).

Ethnic Jews constituted a small but noticeable and flamboyant part of the writing community. The former Kharkivite, writer, and Russian politician Eduard Limonov (Savenko) (b. 1943) once shared a much broader observation with his readers: "If there were no Jews in Kharkiv, the city would be so boring. It is not nice when the entire population has the same temper. If only, say, calm and sedate Ukrainians wandered around the cityhow boring it would be. Jews animate Kharkiv, making it a market place and representing the East in it" (133). Limonov became a successful professional writer decades after he left Kharkiv for Moscow, and later for New York. But he was among the first Kharkiv writers who offered readers a "taste" of bohemian literary Kharkiv, conceived, lived, and perceived as an island of freedom in the re-Stalinized Soviet Ukraine of the early 1960s. ${ }^{13}$ Like many other literati, Limonov has been contradictory in his treatment of Kharkiv, as it seemed to him a bohemian paradise and a cultural backwater from which one needed to escape to Moscow and beyond.

\footnotetext{
12 "Khokhly" is a derogatory term for Ukrainians.

13 For an explanation of the triad "conceived, lived, and perceived" and the connections among perceived social practices, conceived representations of space, and lived spaces of representation, see Lefebvre.
} 
The KGB skillfully exploited a lingering historical hostility between Ukrainians and Jews, and camouflaged traditional state antisemitism with the necessity to fight "Jewish reactionary Zionism" and "inherent Ukrainian antisemitism," a strategy that disturbed both Ukrainians and Jews. ${ }^{14}$ Everyone sensed the disingenuousness of the authorities' rhetoric but largely ignored it. One of the most prominent Kharkiv poets, Marlena Rakhlina (1925-2010), who wrote her poems and memoirs in Russian, once stated: "Certainly, I always felt myself a Jew. Taking turns, Hitler and then Stalin took care of this [perception]. These worries, however, had never been dominant in my life" (90-91). Anatolii Brusilovskii (b. 1932), a famous artist and a son of the Russian writer of Jewish origin Rafail Brusilovskii (18941971) (both were residents of "Slovo," the legendary Writers' Home in Kharkiv), also affirmed that the 1960s was the time of artists and writers, and for him, nation, ethnicity, or the Jewish question instilled by the authorities were not his concerns; instead his focus was culture and art (Studiia; private correspondence with Brusilovskii, 1 Sep. 2017). Rakhlina spent her entire life in Kharkiv; Brusilovskii moved to Moscow, and later to Europe. Both were repulsed by KGB tactics, but paradoxically they preserved affinities with both the Kharkiv culture of the 1960s and the imperial culture that for them had always been centred in Moscow.

The political instability in the 1960s-70s and the escalation of terror against Ukraine's intellectuals contributed to people's mental confusion and ambivalence. The discrepancy between the official Soviet discourse focused on the new unity paradigm, advocating the "friendship of peoples" concept (Tillett; Kolstø; Torbakov 112), and KGB divide and conquer practices further puzzled the Kharkiv intelligentsia. Their existence was essentially a life tied to a tiny space of freedom they created for themselves, a remnant of the Khrushchev Thaw. They valued independent thinking and admired the literary gift in others, an ability that shaped their collective identity. ${ }^{15}$ Their choice, however, included the national: their mental maps and work were populated with images imbedded in their ethnicity, ${ }^{16}$ cultural memories, and

\footnotetext{
14 For a discussion about Soviet state antisemitism and anti-Zionism, see Heiman; Kuzio, "The Soviet Roots of Anti-Fascism and Antisemitism," and Putin's War, 118-26. 15 On the close connection between identity and space, and the flexibility of identity, see Casula 9.

16 Like elsewhere, here the notion of ethnicity refers to people's backgrounds, associated with their culture and the family patterns of upbringing that include their native language, heritage, religion, and customs. In the writers' world, the language(s) in which they write, think, and communicate most frequently, define their membership in an ethnic group. This notion is closely related to the notion of ethnic identity that implies people's social identity, their affiliation with a cultural or social group, and their knowledge about this group's cultural traditions and history.
} 
experiences. Kharkiv's political space systematically adjusted this choice, but what survived unchanged over decades was their sense of spatial belonging. Without thinking about it, they traversed ethnic barriers reinforced by the KGB, yet they were constantly reminded of the fallacy of both-their supranational existence and their sagaciously national literature in which they advanced national themes. Subsequently, the "cursed seventies" and the political space of Kharkiv shaped their ambivalent attitudes toward the city, but likewise they fashioned an unforgettable Kharkiv of the 1960s-70s, a place of hope and creativity.

\section{A "RITUAL VicE": SUBLIMATION OF FEAR}

The years of 1961-62 were marked by literary experimentation and civic courage. The youth contested the old world of conformism and dogmatism. As in Moscow, Kyiv, and Lviv, Kharkiv poetry concerts became extremely popular. Crowds of people packed lecture and concert halls to hear poets reading their verses. The chief editor of the Kharkiv literary journal Prapor (Banner) Iurii Makhnenko recalled that Kharkiv halls were usually packed and could not accommodate all those who tried to get in (Zinkevych). ${ }^{17}$ "Shistdesiatnytsvo," also known as the revolution of poets, liberated people from their fears, awakening their dormant gravitation toward freedom and creativity.

At the time, Prapor became the podium for many "shistdesiatnyky."18 Yet in 1963 the local authorities, inspired by Khrushchev's ideological pogrom at the March 7 meeting with the intelligentsia in Moscow, ${ }^{19}$ curtailed Ukraine's literary renaissance and the literati's attempts to embrace the liberal principles affirmed by the Twentieth Communist Party Congress. The litmus test was the hijacking of the January 1963 issue of Prapor by censors for four months (from October 20, 1962 to January 24, 1963). The intellectual hunger of Prapor's readers, developed during the Khrushchev Thaw, was satisfied when, after the delay, the issue was finally published:

17 Zinkevych's essay was initially published in Smoloskyp (Jul.-Aug. 1963) and republished in Literaturna Ukraina, no. 14 (5302), Apr. 9, 2009.

18 The first issues of the journal Prapor appeared in 1956. In 1991 it was renamed Berezil'. At different times the chief editors were Iurii Shovkoplias, Iurii Barabash, Natalia Cherchenko, Ivan Maslov, and Iurii Stadnychenko. Since 2000, Volodymyr Naumenko has served as Berezil"s editor (Mykhailyn, Literaturna Kharkivshchyna 19).

19 Listen to Khrushchev's shameful attack against Andrei Voznesenskii at this $\begin{array}{lllll}\text { meeting on } & \text { YouTube, 2010, }\end{array}$ https://www.youtube.com/watch?v=3f9izHJGIoo. Accessed 20 Dec. 2019. 
every single copy of Prapor's circulation of 7,800 was sold immediately. But beginning in February 1963, the content of Prapor dramatically changed: new literature written by young promising writers was replaced by works resembling that of the Stalinist era (Zinkevych). As Feliks Rakhlin (b. 1931) has metaphorically stated, censored poems evoked an image of stumps, trees that had been mercilessly mutilated (65). To appear in the press, they had to be unrecognizably distorted and purified of seditious and national allusions (Goble).

Escalated by Moscow ideologues, the rhetoric of fighting Ukrainian nationalism disenchanted Kharkiv writers. Many among the members of the Writers' Union could not handle the stress of surveillance that became quite obvious in late 1964 (Kas'ianov 47). They fell into the abyss of alcoholism and conformism. On March 16, 1963, the Ukrainian writer Iryna Zhylenko (1941-2013) from Kyiv wrote in her diary: "Oh God, how much the boys are drinking here [in Kharkiv]! Horrible ... There is an acute and musty smell of a war in the air" (352). Her second visit in December 1963 confirmed her fears. The Kharkiv intelligentsia was hopelessly and constantly drunk: "We went to visit Kharkiv. I remember a vigorous discussion at Kharkiv University, where we read our poetry. What is left in memory is how the Kharkiv poets were irrepressibly drinking, showing up at our hotel with a bag of alcoholic beverages" (Zhylenko 166).

The 1964 Brezhnev coup, ousting Nikita Khrushchev as General Secretary of the CPSU, entailed significant changes in the Kremlin's political course, particularly in the nationalities policy. Brezhnev's closest associates, Mikhail Suslov, Iurii Andropov, and Nikolai Tikhonov, helped the new General Secretary rejuvenate the Stalinist methods of governing. In August and September of 1965, some twenty individuals were arrested for possession of "samvydav." Among them were Ivan Svitlychnyi, Sviatoslav Karavans'kyi, Valentyn Moroz, Mykhailo and Bohdan Horyn', Mykhailo Osadchyi, and Ivan Hel'. The Dziuba and Chornovil affairs and the subsequent 1968-69 arrests of the Ukrainian intelligentsia confirmed the Kharkivites' worst fears: the regime had rolled back to brutality and violence (Bilocerkowycz; Kas'ianov; Bertelsen, "Political Affinities" 397).

The censors followed the trend. The secret May 31, 1968 report to the Central Committee, produced by the head of the Administration of Preservation of State Secrets in the Press M. Pozdniakov, reveals that the Holovlit, Ukraine's main censorship institution, managed to thoroughly monitor 1600 republican, oblast, city, district, and institutional newspapers, 71 literary and thematic journals, and 234 scholarly and popular journals published in Ukraine (TsDAHOU, 1/25/17/68-77). The editor of Prapor and heads of its main departments were carefully watched by the Holovlit and chastised for the slightest unintentional errors that seemed political to Holovlit inspectors (TsDAHOU, 1/25/17/75). During this time the Holovlit 
was ordered to create a new department that should monitor and control literary and artistic production in Ukraine (TsDAHOU, 1/25/17/77), a move that was followed by the January 7, 1969 directive issued by the Central Committee in Moscow that ordered an increase in party bureaucrats' personal responsibility for ideological deviations in the media, in cultural institutions, and in every publication printed in the USSR (Kas'ianov 80).

By 1970, state antisemitism and anti-Zionism had regained the militant contours of the Stalinist era. Jewish nationalism, inspired by Israel's victory in the 1967 Six-Day War against the neighbouring states of Egypt, Jordan, and Syria, and the Soviet Jews' desire to assert their cultural rights in the USSR or to emigrate to Israel, drove the KGB into active mode. In Ukraine, the main concern was the attempts of Jewish youth to reach out to Jewish intellectuals to revitalize Jewish culture, and the rapprochement of Ukrainians and Jews among the intellectual elite. KGB operatives intensified surveillance, investigated people's connections and habits, and conducted interviews with ideological deviationists in KGB headquarters (HDA, 16/1/1034/176-77). During individual conversations, through intimidation, they turned Jewish wives against their Ukrainian husbands, writers of Ukrainian or Russian origin against writers of Jewish descent, and vice versa (Kasha; interview with Tret'iakova, 19 July 2005; Starodub).

Disillusioned and depressed, the writers gathered daily at the Prapor headquarters and the Writers' Union, discussing politics, reading poetry, and drinking. Soon it became clear that the KGB had bugged the building, and the Kharkiv writers ceased talking politics there. They also avoided political discussions with writers from Lviv and other Ukrainian cities who were critical of the Soviet regime. The guests did not quite understand this behaviour, attributing it to the Kharkivites' pro-Soviet position (Horyn' 29495).

To be safe, the writers moved their gatherings to cafés and private apartments, but the spatial relocation did not change the routine. Alcohol made them talkative, liberating the thoughts otherwise trapped inside cautious minds. For many, an escape from reality became a "ritual vice" ("ritual'nyi porok"), to use the Russian scholar Iurii Lotman's term. Lotman has argued that, from a semiotic perspective, poetry transformed alcohol consumption from a physiochemical process into a fact of culture, where a poetic masterpiece was a sublimation-product. Many Kharkiv writers had this vice. The administrator of the Writers' Union Serhii Boltryk stated in an interview that "Everyone drank-Ukrainians, Russians, and Jews. What varied was the length of time each of us managed to stay sober." The writers' all-pervasive alcoholism, however, became a concern for the KGB. The pernicious habit was associated with having too much freedom. The Russian writer Andrei Bitov most accurately explained this connection. He was convinced that a writer needed a drink to write-to liberate his characters 
and make them talk: "Under the influence, I am giving them freedom to talk about anything; or possibly I acquire freedom from them to write" (Bitov; Zolotonosov).

The problem of Kharkiv writers' drinking habits reached Kyiv, and in May 1971, Fedorchuk wrote a report to Shelest in which several writers were blacklisted: Radii Polons'kyi (1930-2003), Robert Tret'iakov (193696), Aleksandr Cherevchenko (b. 1942), Boris Silaev (1929-2005), Lev Galkin (1913-92), and Vasilii Omel'chenko (b. 1931). The KGB leader also expressed his doubts about their ideological fitness and ability to represent the Kharkiv chapter at the VI Congress of the Writers' Union. Fedorchuk suggested that the Kharkiv chapter, in contrast to the Kyiv chapter, seemed to be less divided, but the symptoms of stagnation and ideological unorthodoxy were there. Beyond the writers' alcoholism, Fedorchuk was concerned about the poet Roman Levin who systematically slandered the Soviet system, Chichibabin whose poems were permeated with antiSovietism, and Polons'kyi who adopted a nationalistic stance. According to KGB operational documents, Polons'kyi privately stated: "We should treat Russians as colonizers [...] The writers' mouths are tightened up, and they cannot write what they want" (HDA SBU, 16/1/1017/6-8). Decades later, another Ukrainian intellectual who closely communicated with Kharkiv writers, the director at the theatre "Berezil'," Anatolii Starodub (1948-2015), confessed in an interview: "We drank too much and talked too freely, and one day we might say too much to a wrong person or to a foreign guest [...] our alcohol consumption was for sure a problem for the KGB." 
Figure 1. Members of the Kharkiv chapter of the Writers' Union in the 1960s. Courtesy of the Central State Archive-Museum of Literature and Art of Ukraine, Kyiv, Ukraine. ${ }^{20}$

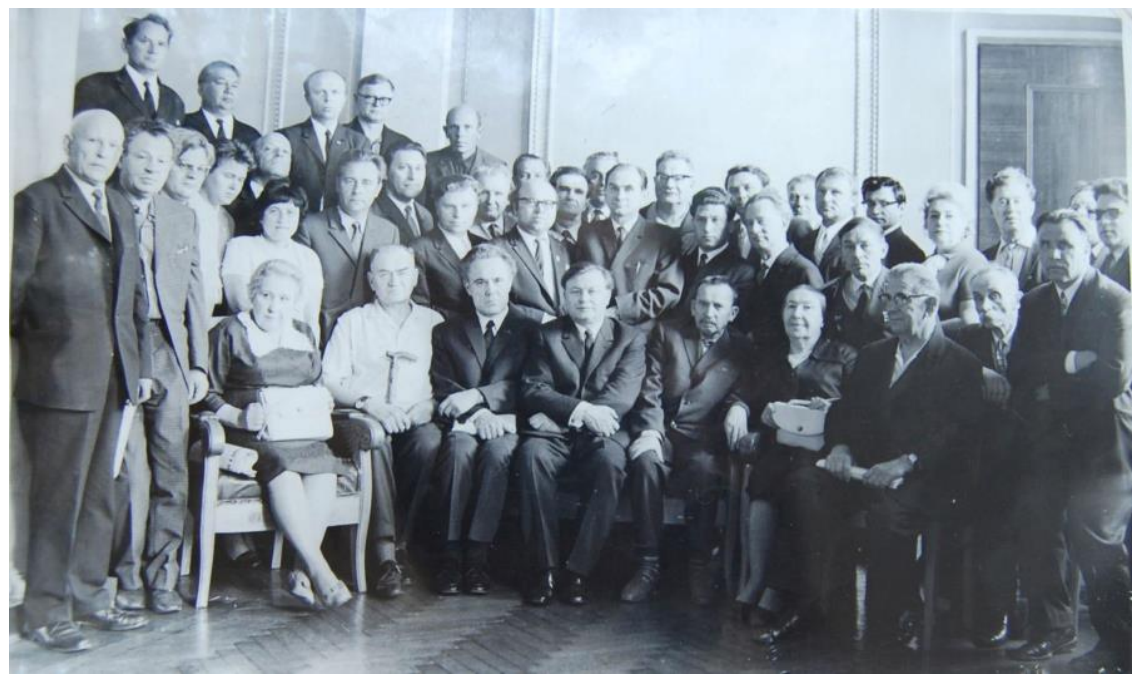

The writers' gatherings and their ritual vice united Ukrainians, Russians, and Jews in the face of danger, which emanated from the KGB. This ritual enabled them to write, to secretly read their unpublishable works to one another, and to collectively produce ironic, sarcastic, and "difficult" poetry (Cherevchenko, "Bunt bessmyslennyi i besposhchadnyi?"). The literati drank enthusiastically and devotedly. Aleksandr Basiuk (years of life are unknown), Vladimir Motrich (1935-97), Leonid Osmolovskii (Osadchuk) (1940-?), and Stanislav Shumyts'kyi (1937-74), among others, became an inseparable part of the writers' memoirs about their pernicious habit (Vernik). The KGB pressed the leadership of the Writers' Union to break this union and to punish those who frequently were seen drunk (interview with Polons'kyi, 16 May 1988).

The early sixties protocols of the Kharkiv chapter of the Writers' Union reveal that attempts by its leadership to alter their members' habits had limited success. For instance, two talented writers of unique literary gift and innovative style, Vladimir Dobrovol'skii (1918-2003) and Vasyl' Bondar (1923-69), were frequently chastised for their alcoholism (DAKhO, R6165/1/134/70,71,93,99; DAKh0, R-6165/1/144/12; Sharova). In the view of KGB literary experts, both individuals wrote ideologically doubtful prose and poetry: in his novels I dukh nash molod (Our Spirit Is Young) and Za

${ }^{20}$ TsDAMLIMU, Fond 783, op. 1, spr. 26, ark. 4. 
nedeliu do otpuska ( $A$ Week Before Vacation), Dobrovol'skii, a 1949 laureate of the Stalin Prize, "slandered the Soviet system, depicting the insufficient optimism of the Soviet youth and the nepotism of the current regime" (Kasha). As a former prisoner of war and a survivor of the Dachau concentration camp, Bondar had no prospects for publishing his work, yet the few poems that he did publish before his death were interpreted as "ones that glorified the suffering and the struggle of World War II prisoners, offering metaphors evoking parallels between the Nazis' and the Soviets' violence" (e.g., "Chorne nebo zhorstoko katuie" ["The Black Sky Violently Tortures"]) (Kasha). Dobrovol'skii was systematically reprimanded; Bondar's membership in the Union was under threat.

Despite the stigma perpetuated by the KGB, Bondar was respected and admired by his fellow writers, and gathered around himself people of various ethnic backgrounds. Together with other prisoners, he was liberated from Dachau by American troops. He went through the American DPs (displaced persons) camp and the Soviet filtration camp in eastern Germany. After his return to Ukraine, he shared his knowledge and experiences of the Holocaust and the Nazis' brutality with the younger writers. Being a perpetual suspect and incessantly guilty because of his imprisonment experience, Bondar also had a tragic individual history. He fell in love with a woman, but when Vasyl' was arrested by the Nazis, she married and bore two children with his brother. Vasyl"s brother died at the front, and Vasyl' married his widow upon his return home, whom he never stopped loving. Difficult memories about Dachau and routine persecution by the KGB prompted Vasyl' to seek relaxation in alcohol which complicated the couple's life. During a fight, his wife confessed that it was his brother who betrayed Vasyl' and surrendered him to the Nazis. Later, the couple divorced (Marchenko; Kryvenchuk). 
Figure 2. Vasyl' Bondar (left) and Radii Polons'kyi (right), 1966. Courtesy of the Central State Archive-Museum of Literature and Art of Ukraine, Kyiv, Ukraine. ${ }^{21}$

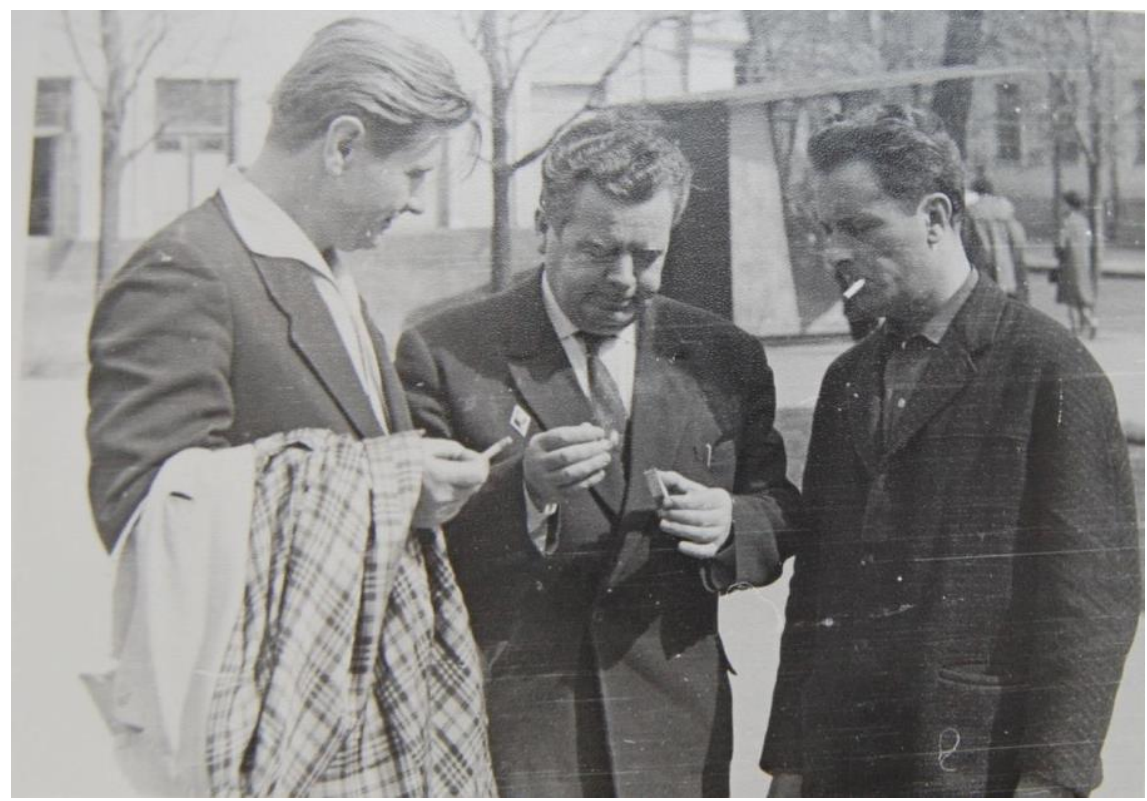

In the early 1960s, to antagonize Jewish and Ukrainian members of the Writers' Union, the KGB spread a rumour that ethnic Jews insisted that Bondar, an ethnic Ukrainian, should be excluded from the Union. Iurii Zbanats'kyi (1914-94), head of the republican chapter, made a special trip from Kyiv to Kharkiv to defend Bondar (DAKhO, f.R6165/1/134/70,71,93,99; DAKhO, f. R-6165/1/144/12). An influential figure, Zbanats'kyi did not acquiesce and ignored the divisive rumours, suggesting that Bondar experienced difficulty in social adjustment and needed the friendly support of the writers' community. Zbanats'kyi farsightedly kept silent about the political reasons inciting Bondar to drink (DAKhO, f.R-6165/1/134/70,71,93,99; DAKh0, f. R-6165/1/144/12).

The members of the Union were hesitant to take radical measures and delayed their decision in Bondar's case until the following year. The administrators of the Writers' Union were frightened because they could be accused of violations of Communist Party discipline. In the party's eyes, they were responsible for the morale of their colleagues. Yet the KGB's divisive tactics failed. Two highly regarded writers of Jewish origin, Union members

21 TsDAMLIMU, Fond 781, op. 1, spr. 72, ark. 6. 
Ihor Muratov (1912-73)22 and Zel'man Kats (1911-2008), saved Bondar, suggesting a softer measure and a compromise that would help the suffering writer-expelling Bondar from the Union for only a year and supporting him while he would receive treatment in a rehabilitation clinic. Alternatively, the oldest members of the Union, Ivan Vyrhan (1908-85) and Vasyl' Mysyk (1907-83), asked the Union to grant Bondar another chance and to sustain his membership. The majority supported Vyrhan's and Mysyk's request and voted for obliging the Literary Fund ("Litfond") to finance Bondar's retreat at a rehabilitation clinic (DAKhO, f.R-6165/1/144/12).

The suffocating atmosphere in Kharkiv culminated in the early 1970s. Volodymyr Shcherbyts'kyi, who replaced Shelest as Ukraine's party leader, together with Fedorchuk and Ukraine's party ideologue Valentyn Malanchuk, choked the dissident and cultural nationalist movement in Ukraine. Beginning from January 12,1972, within a half year approximately 100 people were arrested, and tens of thousands were terrorized through interrogation and fired from their work. Among them were Ivan and Nadiia Svitlychni, V"iacheslav Chornovil, Vasyl' Stus, Ievhen Proniuk, Iryna and Ihor Kalynets', and Stefaniia Shabatura. The Kharkiv chapter of the Fifth Directorate and its head, Colonel Dubrava, created an unbearable atmosphere for many writers (Cherevchenko, "Druz'ia davno minuvshikh let"). Because of the fear of arrest, some developed claustrophobia and were eager to move elsewhere. Limonov escaped to Moscow, Cherevchenko to Magadan. The KGB operation "Blok" targeting Ukraine's intellectuals and the climate of terror exacerbated the drinking habits of Kharkiv writers and tamed the most talented and innovative into submission. Tragically, the KGB drove some to commit suicide. Others died under mysterious circumstances. Among the tragedies that stunned the community of writers were the ones experienced by Bondar, Shumyts'kyi, Osmolovskii, and Tret'iakov (Polons'kyi; Shatylov 158, 173; Marchenko; Cherevchenko, "Trava zabveniia"). ${ }^{23}$

Most Ukrainians were systematically called to make an appearance in the "obkom," where they were threatened and questioned about their friendships with Jews. A functionary in the "obkom" frankly told a Ukrainian

22 Muratov was born in Paris to the family of a professional revolutionary, SRer Levant Maksudovych Muratov (Leontii Maksimovich Muratov, according to his Soviet passport) and the young Kharkivite from a wealthy Jewish family Ievgeniia Iosifovna Rozenbaum (a relative of Charlotte Embden [Rosenbaum], aka Charlotte Heine, sister of Heinrich Heine) (Muratova).

23 Both Bondar and Shumyts'kyi were inconvenient for the authorities-the former for his concentration camp past, the latter for his openly hostile stance toward the local bureaucrats. According to many memoirs, they were likely murdered by the KGB. 
writer: "I do not understand what you are doing among those Jews. They always stick together, and there is no place for you in this Zionist group. I am just trying to help you. You need to publish, don't you?" (Marchenko). Similarly, Jews were questioned about their bonds with Ukrainians: "Stay away from him, he is a Ukrainian nationalist. You'll be in trouble like him. Just warning you" (interview with Briuhhen, 2 July 2011).

The writers had to endure lengthy tirades and instructions by the "obkom" and KGB leaders in their offices and elsewhere about how and what to write (Bertelsen, "Shistdesiatnyky"). For instance, works by the Russian writer of Jewish origin David Vishnevskii (1910-77) were viciously criticized by Communist Party functionaries. In the late 1970s, the first secretary of the Kharkiv "obkom" Mykola Siroshtan accused Vishnevskii of tarnishing the heroism of Soviet soldiers during World War II in his new novel. Siroshtan suggested that Vishnevskii should align his writings with examples of literary excellence and historical truth, such as Leonid Brezhnev's memoirs Malaia Zemlia (The Small Land). Vishnevskii constantly redrafted the text but Siroshtan was adamant: "It won't fly" (Shatylov 100-101). ${ }^{24}$ Vishnevskii's colleagues sympathized with his situation, as the majority were under similar pressure.

Despite the increasing terror precipitated by the KGB, the writers tried to grasp what was happening around them and within them, continuing to gather in downtown Kharkiv. The most frequent places for their meetings were the café "Avtomat" (later the Kharkiv literati gave it the nick-name "Pulemet" ["A Machine Gun"]), a hand-made little waterfall adjacent to the Park of Victory called "Dzerkal'nyi Strumin"' ("The Mirror Jet") on Sums'ka Street, the restaurant "Kryshtal"' ("Crystal") in the heart of Shevchenko Park, the legendary bookstore "Poeziia" ("Poetry") on Poetry Square, ${ }^{25}$ and Chichibabin's apartment on Rymars'ka Street (Filatov, "Vdogonku"; Orlov; "Ievtushenko i Khar'kov"; Limonov 31, 104, 155; Omel'chenko "Tam zhili poety..."). A few writers resided in the House of Writers "Slovo," where the majority of their predecessors - known as writers of the Red Renaissance-

24 Brezhnev's trilogy of memoirs was published in the Moscow journal Novyi mir (New World) in 1978-Malaia Zemlia (The Small Land) in the second issue, Vozrozhdeniie (Rebirth) in the fifth issue, and Tselina (Virgin Lands) in the eleventh issue. The circulation of each issue was approximately 15 million.

25 In the 1960s, Ievgenii Ievtushenko, hoarse from reading his poetry outside the doors of this bookstore, receiving a bottle of warm milk tied on a rope, dangling from some caring fan's balcony; in the late 1980s, at the same Poetry Square, in the presence of thousands of Kharkivites, including the author of this article, Ievtushenko granted Chichibabin his membership card, when Chichibabin's membership in the Writers' Union was finally restored (Ievtushenko; interview with Polons'kyi, 16 May 1988; "Ievtushenko i Khar'kov"). 
suffered a tragic fate. A cultural marker of the 1930s, "Slovo" lost its significance in the 1960s-70s, but it remained under surveillance, as did the places mentioned above. Brusilovskii believed that the main problem with the writers was that they were excessively chatty (Studiia). This factor, as well as the close proximity of these places to the KGB headquarters on Chernyshevs'kyi Street, facilitated the task of surveillance. Regardless of the writers' will, Kharkiv's political space delineated and absorbed the cultural space they created for themselves, threatening to abrogate their existential values, imaginations, and practices. To better understand these dynamics, a discussion of the inter-ethnic communication and cultural exchanges of the Kharkiv literati will follow.

\section{ThE “JeWish Question” AND The Writers' Cultural GRAvitations}

The members of the Writers' Union enjoyed perks and privileges in the form of paid or heavily subsidized vacation trips, awards, and access to scarce consumer products and food offered by the Union (Garrard). The Union also provided the writers with an opportunity to earn additional income by reading their work at factories before large audiences. The Kharkiv chapter could afford to send its members to Moscow or Kyiv, where the Union's congresses were typically held. Writers' Union membership was often employed as a tool of control and manipulation by the "obkom" and the KGB, yet the writers welcomed these opportunities at the expense of their liberty and integrity.

Like most of the Union's chapters, the Kharkiv chapter was ethnically diverse. Communication and the relationships among Ukrainians, Russians, and Jews appeared to be peaceful and free of serious conflicts, in contrast to the constant tensions that could be observed among Moscow literati (Omel'chenko, Smutnye gody 388). An antisemite and Stalinist, the Russian writer from Moscow Vladimir Bushin (b. 1924) was shocked by how freely Viktor Koptylov (1930-2015), a Kyivite, and Andrii Chernyshov, a Kharkivite, discussed the Jewish question in Koktebel (Crimea) in front of Volodymyr Briuhhen (1932-2018), a literary critic from Kharkiv with Jewish-German roots (Bushin). 
Figure 3. Volodymyr Briuhhen (left), Nina Polons'ka, and Radii Polons'kyi (right) with the Polish writer Sat-Okh, 1978. Courtesy of the Central State Archive-Museum of Literature and Art of Ukraine, Kyiv, Ukraine. ${ }^{26}$

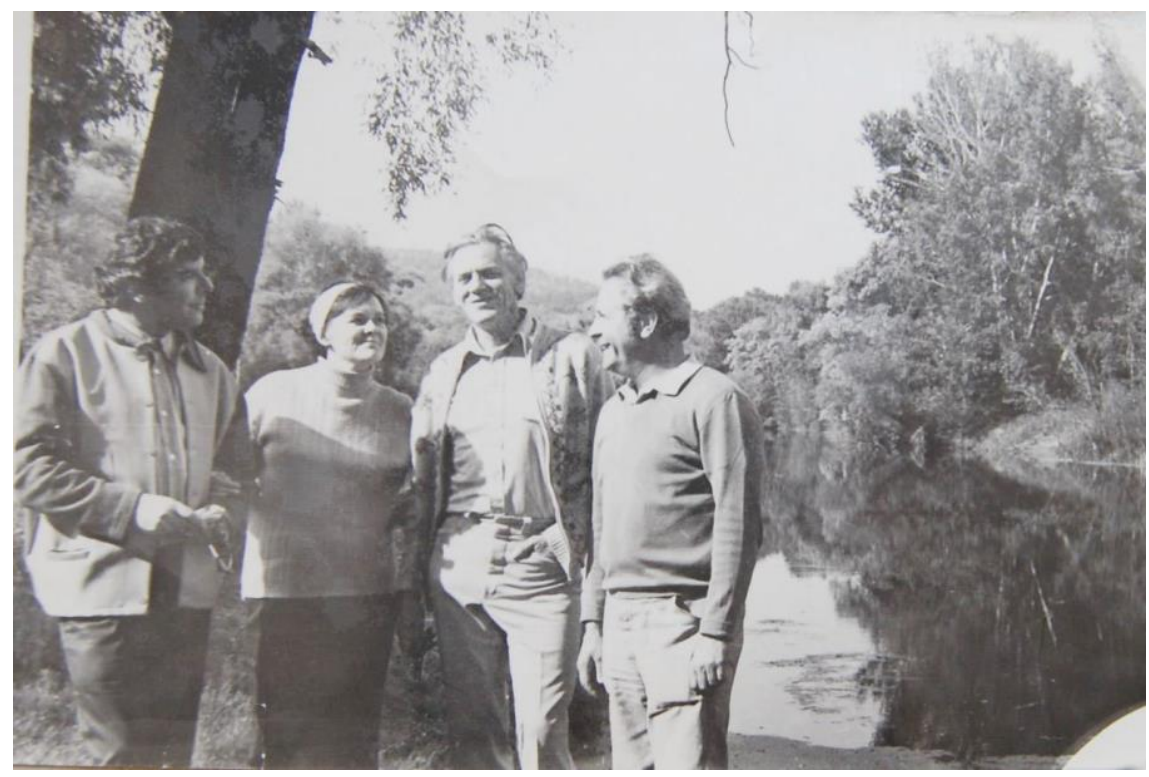

Indeed, the Jewish question has never been a forbidden topic for Kharkiv writers. As noted earlier, the KGB used it as a divisive tool and encouraged the Union's members who co-operated with the KGB to bring it occasionally to the surface in their private conversations to identify the position of the writers on this sensitive topic (interview with Briuhhen, 27 July 2011). As a result of provocateurs' attempts, the topic ceased to be difficult. Briuhhen wondered: "If the KGB, the Communist party, and KGB people in the Union raise this question daily, why cannot we do the same just for the hell of it? At least, we can have fun and get humour out of the way" (interview with Briuhhen, 27 July 2011). Yet, Briuhhen added that Jews were more sensitive than Ukrainians or Russians to any type of jokes, suspecting antisemitism (Bloknoty 48). But typically, ironic remarks that were often grounded in the interplay of words and stereotypes were taken with ease by writers. For instance, the satirical gift of Aleksandr Khazin (1912-76) helped him produce a statement memorable among many Kharkiv literati. In his view, the talented poet Boris Sukhorukov (?-1976) had a unique phenotype,

26 TsDAMLIMU, Fond 781, op. 1, spr. 72, ark. 2. 
possessing both Slavic and Jewish features. This somatic phenomenon provoked Khazin's joke: “From the front, Sukhorukov looks like the organizer of the Jewish pogrom, and from behind-like its victim" (Rakhlin 94). Everyone was aware of Sukhorukov's rejection of antisemitism. He, like many of his Russian and Ukrainian colleagues, had a Jewish wife, the poet Anna Fisheleva (1923-2001). Khazin's joke was appreciated by Sukhorokov and his Jewish friends, and has been reiterated by three generations of Kharkiv literati.

In the 1960s, two Ukrainians and a Jew served as heads of the Writers' Union: Viktor Kochevs'kyi (1923-2005), Iaroslav Hrymailo (1906-84), and Muratov (Mel'nykiv 21; Pererva 19; interview with Pererva, 17 July 2017). The Union's administration included nine people-five ethnic Ukrainians, two ethnic Russians, and two ethnic Jews (DAKhO, f.R-6165/1/134/116). Among the 48 members of the Union, there were 17 ethnic Jews who wrote mostly in Russian. Muratov and Briuhhen used both languages, Ukrainian and Russian, and only two writers, Khana Levina (1900-69) and Oizer Gol'des (1900-66), wrote in Yiddish. Three decades of Soviet russification and assimilation practices resulted in a dramatic reduction of Yiddishspeakers. Levina's and Gol'des's colleagues called them "the last of the Mohicans," using the title of James Fenimore Cooper's book, popular at the time in the Soviet Union.

The Yiddish-language literary journal Sovetish Heymland, based in Moscow, was the only outlet for Levina and Gol'des to publish their work. The journal was quite popular among Yiddish-speakers, but over the years that followed the 1967 Six-Day War, when the journal was populated with texts of anti-Zionist propaganda, the number of its subscribers fell dramatically. With a population of two million, Kharkiv received only 68 copies of the journal for retail sales through the Soiuzpechat' network (Estraikh 128). With the death of Gol'des in 1966 and Levina in 1969, the Writers' Union in Kharkiv had no Yiddish-language writers.

Kharkiv, a crossroads of multiple cultures and languages, nurtured the literary talents of Ukrainians, Russians, and Jews, but by 1970, its language space had been narrowed to two languages-Russian and Ukrainian. Zhabotinskii has argued that "to write in Russian does not exactly mean to abandon Jewish literature . . . the 'nationality' of a literary product is not defined by the language in which it was written." He further suggested that the ethnic origin of the writer means little, and that it is the writer's attitude and intended audience that is important. One who does not know Yiddish but who writes for Jewish people and appeals to them, does not abandon the Jewish literature. Similarly, Chichibabin has posited that "[t]he place of a Jew is in a culture, in which he discovered himself" ("Da budet volia tvoia'”).

Regardless of the language in which Kharkiv writers wrote, they contributed greatly to other cultures, writing for and about the peoples of 
these cultures. An ethnic Russian, Chichibabin was famous for his Jewdophilia, discovering and falling in love with Israel and Jewish culture (Stikhotvoreniia 254-57). A German Jew, Briuhhen wrote equally gracefully and eloquently in Ukrainian and Russian, and translated from French, Polish, and English. He was surprised when asked whether he gravitated more to Ukrainian, Russian, Jewish, or any other culture, and replied, "You are trying to fill in the blanks, and there are no blanks in my life. They are all culturally filled in a variety of linguistic and intellectual ways" (interview with Briuhhen, 16 July 2015; Briuggen [Briuhhen], Bloknoty 295).

An ethnic Ukrainian, Cherevchenko graduated from the Moscow Literary Institute and established himself as a subtle Russian poet. His volume of poems Koleso (The Wheel) published in 1966 demonstrates the emotional and intellectual depth that astonished his readers. Possibly, the intimacy of his poetry and a lack of texts dedicated to Lenin or the Communist Party provoked the KGB to give him an ultimatum: to mature ideologically and stay in Kharkiv, or alternatively to move to the North "on his own initiative" (Cherevchenko, "Trava zabveniia"). Cherevchenko preferred Magadan to the Kharkiv prison. In the North, he reinvented himself as a translator, translating poetry from Sami, Khanty, Evenki, Yukaghir, and Nanai languages. Oddly, the years spent in Russia (and later in Latvia) had transformed him into a Russian nationalist, yet he preserved warm feelings toward the Kharkiv of the 1960s and his fellow writers, especially toward his friend Robert Tret'iakov (Cherevchenko, "Trava zabveniia").27

An ethnic Russian, Tret'iakov wrote in Ukrainian, having become in the late 1950s-early 1960s a legend among the youth because of his charismatic character, poetic innovations, and the intellectualism of his poetry (Hundorova; private correspondence with Briuhhen, 2010-18; interview with Mykhailyn, 13 May 2015). He was born in Perm, Russia, but after World War II, he, with his mother, moved to Ukraine. His Ukrainianness was nurtured by the atmosphere of the small village of Smila in Kyiv oblast where they narrowly survived the famine of 1946. In 1961 Tret'iakov published his first volume of poetry entitled Zorianist' (The Galaxy), joining the ranks of "shistdesiatnyky." The Galaxy illuminated the birth of a unique poetic voice, suppressed in the 1970s to be brought back to life in independent Ukraine when he published a volume of his intimate lyrical poetry Tobi (To You). His translations from Yiddish, Kazakh, and Russian astounded professionals by

\footnotetext{
${ }^{27}$ In his most recent poems, "Liubite Rossiiu" ("Love Russia”) and "Gimn rusofobam" ("The Anthem to Russophobes"), Cherevchenko called on readers to love Russia precisely because it is being "zoologically hated" by Russophobes, arguing that at the present time Russia is being rejuvenated as it was during the Peter the Great era. See "Aleksandr Cherevchenko."
} 
their precision and the thorough treatment of the original text. Tret'iakov remains the only Ukrainian translator of Sergei Iesenin's long poem "Anna Snegina," and his translations of Levina's Yiddish works helped her reach out to Ukrainian-speaking audiences (Levina). In 1958, Tret'iakov graduated as a journalist from Kyiv State University, together with Borys Oliinyk, Valerii Huzhva, Iurii Iarmysh, and Mykola Il'nyts'kyi. Having embraced the Ukrainian language and culture, he identified himself as a Ukrainian poet. Yet, interestingly, he refused to Ukrainianize his last name and to betray the memory of his father, an ethnic Russian, who went missing in action during World War II. Humble but emphatic, Tret'iakov wrote, "Do not remove the soft sign from my last name" ("Ne vyluchaite z prizvyshcha moho toi znak pom"iakshennia, shcho vam zdaiet'sia zaivym"), a poem that proclaimed his deep love for Ukraine and asserted his loyalty to his ethnic roots. ${ }^{28}$

These four writers, Chichibabin, Briuhhen, Cherevchenko, and Tret'iakov, are only a small sample of the remarkable talent assembled in the Kharkiv of the 1960s - an ethnically diverse community of writers with distinct and pronounced cultural and regional affinities, amalgamated and overlapping multiple identities, intense intellectualism, and inimitable poetic styles.

\footnotetext{
${ }^{28}$ When Tret'iakov had received his new passport, a bureaucrat insisted that his last name must be spelled without the soft sign in Ukrainian. The poet rejected the idea, demanding a new passport.
} 
Figure 4. Radii Polons'kyi (left) and Robert Tret'iakov (standing right) in the 1960s. Courtesy of the Central State Archive-Museum of Literature and Art of Ukraine, Kyiv, Ukraine. ${ }^{29}$

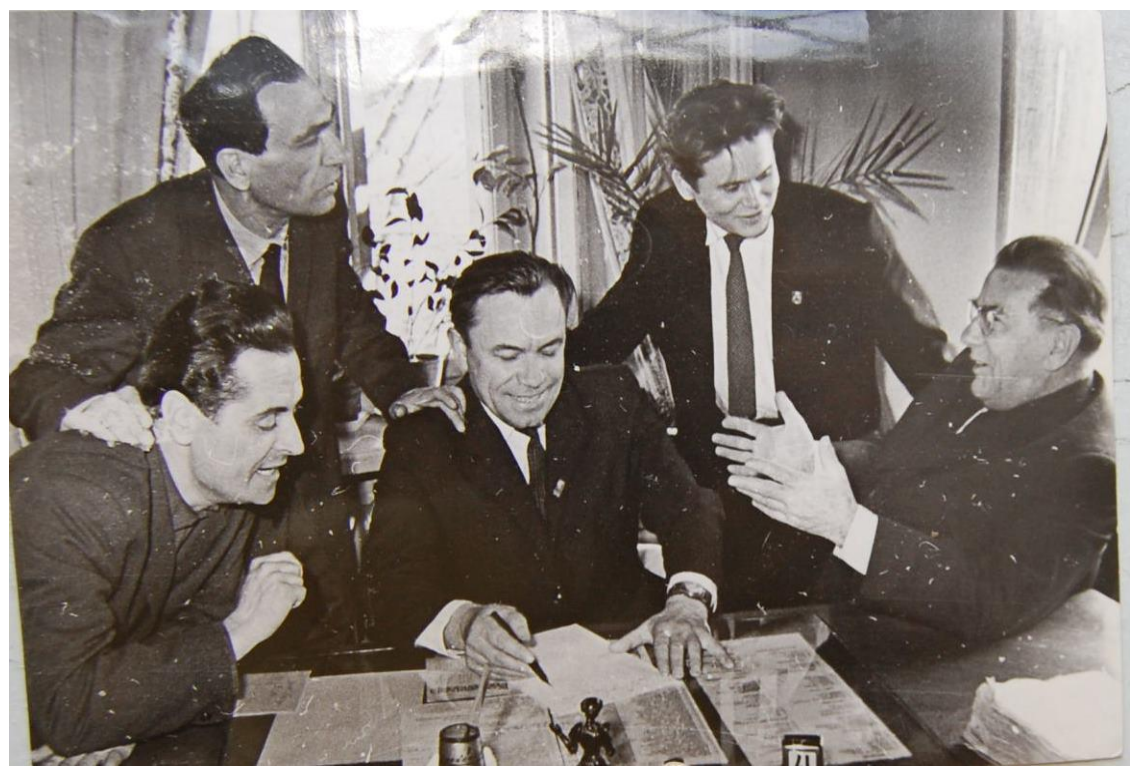

Most importantly, their friendship blossomed precisely out of this diversity-differences in ethnic and social backgrounds, cultural gravitations, bilingualism, and trilingualism. They were new and interesting to each other, and their shared spatial ambivalence amplified the existential feeling of togetherness that was so much needed in the space of terror and state violence. Governed by antisemitic and anti-Ukrainian Communist Party bosses, the Kharkiv of the "cursed seventies" taught them to appreciate "literary brotherhood, talent, and professional competence" (interview with Briuhhen, 16 July 2015). Affiliation with the Writers' Union was not what Briuhhen meant by brotherhood. The elitist club had many extremely gifted writers who elevated the standards of literary product for others. Most belonged to the Kharkiv post-war generation, and the calibre of their intelligence and literary gift was indisputable. Their reputation, "organic culture, intelligence, and talent" left minimal room for moral compromise, and thus not ethnic solidarity but principles and respect for the literary gift shaped the writers' behaviour and the ways they voted at the Union's meetings (Filatov, "Khrani tebia gospod"').

${ }^{29}$ TsDAMLIMU, Fond 783, op. 1, spr. 24, ark. 6. 
The writers felt privileged to learn and to advance their skills in the company of the best, regardless of their cultural backgrounds. They instantly diagnosed graphomaniacs and developed a subtle understanding and appreciation of rare talents. In 1962, the Ukrainian poet Vasyl' Mysyk published a new volume of his poems entitled Borozny (The Grooves). It became clear to all members that Mysyk's book was an outstanding literary phenomenon that deserved to be nominated for Ukraine's highest literary award-the Shevchenko Award. Hryhorii Hel'fandbein (1908-93) enthusiastically supported the nomination, suggesting that Mysyk's poetry was innovative, powerfully metaphoric, humanistic, and subtle (DAKhO, R65/1/144/22). The Shevchenko Committee granted the 1963 award posthumously to a former Kharkivite, the Lviv prose writer Hryhorii Tiutiunnyk (1920-61) for his novel Vyr (Whirlpool), ${ }^{30}$ but the unanimous support of Ukrainians, Jews, and Russians for Mysyk's nomination is telling. The appreciation of literature rose above possible ethnic pride or cultural affinities.

One exception worth mentioning is Vishnevskii's case, reflected in the minutes of the Writers' Union meetings. A discussion of his new book 72-i den' (The 72nd Day) turned into a four-hour battle at the prose section meeting. The members were divided along ethnic lines on whether the book deserved to be nominated for the Lenin Award, which was no less prestigious than the Shevchenko Award. Writers of Jewish origin argued that the novel was excellent while Ukrainian writers believed its literary value was modest. Yet the majority was adamant: the book seemed weak and did not deserve the nomination. Vishnevskii realized that he had overestimated the value of his novel and withdrew his self-nomination for this award (DAKhO, R-6165/1/144/27-28).

The writers, however, exhibited astonishing unity in their responses to graphomaniacs, regardless of their cultural identity, who routinely showed up at the Union's headquarters to corner the members and read their work to them. The members collectively hid from "prodigies," and their schemes of escape were strategically planned in advance. Assisted by his colleagues, the chief editor of Prapor's poetry department Tret'iakov habitually escaped from a group of graphomaniacs who were determined to conquer this invincible fortress, the Parnassus, and to persuade him to publish their poetry (interview with Tret'iakov, 2 July 1986).

Despite the KGB's persistent efforts to instill hostilities between Ukrainians and Jews, the protocols of the Union reveal no signs of antisemitism or discrimination against Jews. Along with Ukrainians and Russians, they chaired various thematic commissions and committees and

${ }^{30}$ Hryhorii Tiutiunnyk was Hryhir Tiutiunnyk's brother. The second part of the novel Vyr was published in 1962, after Hryhorii Tiutiunnyk's death (Bondarenko). 
were provided opportunities to take advantage of finances available in the Litfund for research purposes and for vacations that the writers typically used for completing a new book (DAKh0, R-6165/1/144/11-12). The writers were generously rewarded for reading poetry before large audiences, including those at Kharkiv factories. From the Soviet point of view, their compensation for one concert (7-8 rubles) was a rare opportunity to earn additional income. Monetarily, two concerts often given by writers in one day provided 15-20 percent of the monthly salary of a Soviet white-collar worker. The writers created teams and preferred to travel to factories in groups. Drained emotionally, they typically celebrated together, relaxing after such concerts. The groups were ethnically mixed. Personal affinities and friendships played a huge role in these arrangements, and the Union's secretary Olena Lukashova scheduled these trips according to the writers' requests. For instance, Aleksandr Kravtsov (1915-83) enjoyed the company of Hel'fandbein, Tret'iakov preferred to join Kats and Osmolovskii, and Iurii Barabash (b. 1931) travelled with Galkin (DAKhO, R6165/1/144/15).

Ethnic origin meant little in the hierarchy of the writers' values. But the absence of any literary gift or basic humanity provoked tensions in the community, as Kravtsov's case demonstrates. Kravtsov was despised by many, and apparently Hel'fandbein was the only person who could somewhat tolerate him. On several occasions, Kravtsov became the main point of discussion at the Writers' Union meetings. His graphomaniac poetry was appreciated by few. Worse, Kravtsov, out of professional jealousy of his talented colleagues, slandered many, spreading insinuations about antiSoviet and immoral poems allegedly written by some members of the Union. Eventually, Kravtsov's antisemitic rants put an end to the Union administration's patience. Kravtsov was reprimanded for his black deeds and was obliged to publish an apology in the local press to all he had offended (DAKh0, R-6165/1/134/). Moreover, Kravtsov's case illuminated the writers' small victory over the KGB. According to some testimonies, Kravtsov had close connections with this powerful agency, and the writers' solid unity and intransigence toward Kravtsov's boorishness and poetic mediocrity was a personal insult to his supervisors. Kravtsov's apologies were accepted but his humiliation was forgotten neither by Kravtsov, nor by the KGB (Starodub; interview with Tret'iakov, 17 July 1996).

Roman Levin (b. 1939) and Vadim Levin (b. 1933) exemplified the writers' gravitation toward and support for literary talent, cases where considerations of ethnic solidarity were not part of the equation. Roman was a writer with modest literary talent; Vadim established a reputation as an extremely gifted poet and thinker, writing poems for children that read as philosophical parables and were much appreciated by adults (Levin). Roman was systematically criticized for his mediocre work and "long speeches 
about nothing" at Writers' Union meetings (Mykhailyn, "Poet v optytsi svoho chasu"). In contrast, Vadim was praised for his subtle ironic poetry and protected by his talented colleagues from unsubstantiated attacks. For instance, at the January 23, 1961 Writers' Union meeting, Tret'iakov appealed to some individuals in the older generation of Ukrainian writers who doubted Vadim's ability to grow into a serious writer. These members even questioned Vadim's maturity, and his ability to read his work before large audiences, let alone his qualifications to be a member of the Union: "What kind of poetry can a person write without life experience?" Tret'iakov mocked this sort of logic, claiming that age never defined the artistic and intellectual magnitude of poetry: "[Vadim] Levin is thirty years old ... and it would be incorrect to think that he cannot write something [that you want him to write] because he is not yet fifty" (DAKhO, R-6165/1/134/48). ${ }^{31}$ Cherevchenko was a vivid example of Tret'iakov's argument: in 1967, endorsed by the Union for his literary talent, Cherevchenko received the prestigious Lenin Komsomol Award, becoming a leading journalist ("spetskor") of the Kyiv newspaper Pravda Ukrainy (The Truth of Ukraine, its Kharkiv chapter), an important outlet at the time. He was only twenty-six years old (Limonov 102).

The official Communist Party position drastically differed from backroom schemes and personal attitudes toward the Jews in the "obkom." Jews occupied important posts in the Writers' Union. For instance, in the 1960s Galkin was the trusted assistant of the secretary of the Union's primary party cell, a nomenklatura appointment made by the Kharkiv "obkom" (DAKhO, R-6165/1/144/16). Hel'fandbein led one of the largest literary studios in Kharkiv despite his past. After World War II he was chastised for "cosmopolitanism," falling out of the Communist Party's favour because of his panegyrics to Leonid Pasternak and Anna Akhmatova. His literary studio was founded under the umbrella of the Writers' Union and located at the Kharkiv factory "Serp i molot" ("Hammer and Sickle") (Mykhailyn, "Poet v optytsi svoho chasu"). For decades, Hel'fandbein was also the chief editor of the Kharkiv newspaper Krasnoe znamia (Red Banner). Yet behind closed doors, state antisemitism and active measures designed by the KGB to break alliances and friendships between Ukrainians and Jews were routine practices of those in power.

High posts in the Writers' Union came not only with privileges but with great responsibilities of ideological flexibility, as the behaviour of Union officials was regimented by the Kharkiv authorities. The political manoeuvres of Boris Kotliarov (1911-89), who in the 1960s was the secretary of the Union's primary party cell, were shameful. At a meeting at

31 Some party functionaries and older writers identified Vadim Levin's poems as "muddy and double-meaning" work (CIA Archive, "A New Freeze" 22). 
one of the Kharkiv factories, he explained the Communist Party's critique of Ievtushenko's poem "Babii Iar" ("Babyn Iar") to the audience as follows: "Friends, please understand, we all sympathize with Jews who were killed by the fascists. But according to Ievtushenko, the fascists killed only them [the Jews], and this is not true" (Rakhlin 70). Kotliarov knew that Ievtushenko's poem denounced a very specific kind of killing, genocide, and a long-lasting tradition of state antisemitism that denied a monument to the victims of this genocide at Babyn Iar. Yet Kotliarov chose to follow the party's talking points and accused Ievtushenko of political short-sightedness.

In the late 1960s, the KGB launched an anti-Zionist campaign, complicating the lives of many Jews. According to an insider, KGB operatives also tried to recruit Jews who were willing to penetrate dissident and literary groups and denounce their members (Usol'tsev, qtd. in Nikash). The KGB even had special departments whose staff specialized in the "Jewish question." They worked on multiple tasks, trying to curtail the Jewish emigration movement and the dissident movement, and to disrupt the rapprochement between Jews and Ukrainians domestically and abroad. KGB active measures threatened the livelihoods of official and non-official writers of various cultural backgrounds. They all faced a dilemma: to denounce and conform; or to stay true to their principles and face the consequences. Some developed close relationships with dissidents in Kharkiv and beyond, solidifying the image of Ukraine's writers as Ukrainian nationalists and Zionists.

\section{SuPRANATIONAL BROTHERHOOD AND THE DisSIDENT MOVEMENT}

The beliefs, interests, and fates of many Kharkiv writers were closely intertwined with those of Kharkiv dissidents. In fact, the writers in this group could also be identified as dissidents for their civic gallantry and support of individuals who were persecuted and prosecuted by the KGB. The dissident movement in Kharkiv was represented by people of various ethnic backgrounds, but Jews and Ukrainians stood out prominently among dissidents throughout several decades of late socialism. The leading figure, however, with whom this movement in Kharkiv is associated most frequently, was Chichibabin, a former gulag prisoner and a member of the Writers' Union who had never become an official writer.

Importantly, the names of Iulii Daniel' (1925-88), Russian poet, Soviet dissident, and son of a Jewish writer, and Daniel"s first wife Larisa Bogoraz (1929-2004), a graduate of the Kharkiv State University's Department of Philology, a linguist, and the daughter of a Jewish professor, embodied the Soviet dissident movement that united Ukrainians, Russians, and Jews. In fact, the 1965-66 trial of Iulii Daniel' and Andrei Siniavskii (1925-97), a 
Russian writer who, like Daniel', published his work abroad under a pseudonym, galvanized the dissident movement by establishing new links among dissidents and writers in Moscow and Kharkiv (Medvedeva).

Although Daniel' served his term in the gulag, he did not become an active participant in the dissident movement after his return. He remained a very private person, resisting the assertive environment created by Soviet dissidents. Unlike many Jewish literati who emigrated from the USSR in the 1970s, he stayed in Russia. He stated: "I am indifferent to the call of blood. Moreover, I cannot imagine myself in any environment other than [Russian] ... My pedigree is Russian, and it is no shorter or poorer than that of the Golitsyns, the Murav'evs, and others .... This is my position, and everyone has the right to decide for himself" (Medvedeva). Like Daniel', Chichibabin lived the quiet life of an accountant, although actively communicating with Kharkiv dissidents and poets of various ethnic backgrounds.

For many like Bogoraz, defending human rights and freedom of speech became their life mission. Love for poetry and friendships, including romantic engagements among Bogoraz, Daniel', Rakhlina, and Chichibabin, created a nucleus and a social glue that bonded many Kharkiv literati. After Bogoraz's and Daniel"s departure to Moscow in 1950, the group was further shaped by "Chichibabin's Wednesdays." In the early 1960s, a diverse group of poets and writers routinely visited Chichibabin's seven-square-metre apartment to chat and to read poetry. The Kharkiv informal literary club initially included five members: Mark Bogoslavskii (1925-2015), Arkadii Filatov (b. 1938), Leonid Pugachev (years of life are unknown), Aleksandra Lesnikova (1927-2008), and Rakhlina (Filatov, "Vdogonku"; Omel'chenko, "Tam zhili poety..." and Smutnye gody). Later, a graduate of the Department of Philology, Iosif Gol'denberg (b. 1927), joined the club. ${ }^{32}$ Chichibabin's salon was significantly extended over the years and every gifted person was a welcome addition to the company.

Beyond literature, intolerance to human rights violations in Soviet society united these men and women, attracting other Kharkiv writers and non-writers to their circle. In a sense, the Soviet dissident movement of the 1970s-80s grew out of this initially small group of people in Kharkiv, a fact of which many scholars are unaware. Due to the members of the 1960s generation Daniel' and Bogoraz, its centre moved to Moscow, but after

\footnotetext{
32 Gol'denberg survived the Holocaust but lost all his relatives in Belarus under the Nazis. In the mid-1960s he departed for Novosibirsk in Russia, where he taught Russian language and literature in "akademgorodok." In 1968, after signing a letter protesting the arrest of the dissidents Aleksandr Ginzburg (1936-2002), Iurii Galanskov (1939-72), Aleksei Dobrovol'skii (1938-2013), and Vera Lashkova (b. 1944), he was fired and deprived of his teaching privileges ("Iosif Gol'denberg"; Rakhlin 42).
} 
Daniel"s and Siniavskii's trial, the links among like-minded people, inspired by Bogoraz's political activism, extended far beyond Moscow and Kharkiv (Zakharov). ${ }^{33}$

A Jewdophile and Ukrainophile, Chichibabin helped expand the geography of the dissident movement, and its ethnic, linguistic, and political boundaries. In the early 1970s, he became acquainted with dissidents in Ukraine - the Kyivites Ivan Dziuba (b. 1931) and Mykola Rudenko (19202004), and the Kharkivites Henrikh Altunian (1933-2005) and Volodymyr Pasichnyk (1935-2013). Like Chichibabin in 1973, Dziuba, the author of the pamphlet "Internatsionalizm chy rusyfikatsiia?" ("Internationalism or Russification?") was excluded from the Writers' Union in 1972. In 1975, the Writers' Union deprived Rudenko of his membership because of his relationships with Moscow dissidents and his protests against violations of human rights in Ukraine. Chichibabin admired Rudenko's bravery when, at the peak of Stalin's antisemitic campaign in 1949, Rudenko refused to negatively characterize Jewish writers who were about to be dismissed from the Union. ${ }^{34}$ Chichibabin shared the views of Altunian, the Ukrainian dissident of Armenian origin who signed a collective letter protesting against the authorities' persecution of General Petro Hryhorenko and demanding the end of discrimination against the Crimean Tatars..$^{35}$ Chichibabin also supported the political activities of Pasichnyk, a Ukrainian poet and dissident, who in 1964, being a last-year student at Kharkiv University's Department of Philology, was expelled for his poetry propagating "bourgeois nationalist ideology" (Kalynychenko). These acquaintances grew into friendships that shaped Chichibabin's affinities toward Ukrainian national aspirations.

Undoubtedly, these cross-ethnic and dissident affiliations were extremely dangerous for people like Chichibabin, and further complicated their professional careers and lives. Yet many members of Chichibabin's circle decided to stay in Kharkiv. They were emotionally attached to this place, a feeling conditioned by their biographies. But there was a deeper and

\footnotetext{
33 Ievhen Zakharkov is Marlena Rakhlina's son and the head of the Kharkiv human rights group "Kharkivs'ka pravozakhysna hrupa."

${ }^{34}$ Rudenko was a Ukrainian writer, human rights activist, and the founder of the Ukrainian Helsinki Group (UHH). In February 1977 he was arrested for anti-Soviet propaganda and agitation and sentenced to seven years in camps and three years of exile. After his release in December 1987, Rudenko emigrated to Germany but later returned to Ukraine in 1990. For more on Rudenko's biography and his political activism, see Rudenko.

35 Altunian, a human rights activist from Kharkiv, was one of the founders of the Initiative Group on Human Rights in the USSR. He was a political prisoner in 1969-72 and 1981-87 (Altunian; Hel' 324-25; Rakhlin 131). See also Grigorenko.
} 
more subtle connection to the city, nurtured by their uneasy past and Kharkiv's multi-ethnic cultural space (interview with Briuhhen, 27 July 2011; interview with Buidin, 18 Dec. 2018). This space, enriched by Taras Shevchenko, Nikolai Gogol' (Mykola Hohol'), and Sholem Aleichem, brought them intellectual satisfaction and joy, but it also evoked feelings of frustration and national humiliation. Because of their shared history and collective trips to their past-to Skovorodynivka, a village near Kharkiv where the Ukrainian philosopher Hryhorii Skovoroda was buried, and to Drobyts'kyi Iar, where thousands of Jews, Ukrainians, and Russians were murdered by the Nazis - many learned to appreciate the city and to live with their ambivalence. ${ }^{36}$

These activities and communication among Kharkiv literati and between Kharkiv literati and representatives of the dissident movement were under constant surveillance by the KGB (HDA SBU, 16/1/985/260). In June 1969, the KGB uncovered an illegal youth group of 100 individuals organized by the Kharkiv Jewish intelligentsia. The group maintained connections with dissidents in other Ukrainian and Russian cities and allegedly planned an armed rebellion in Kharkiv to take over the Kharkiv authorities' buildings and infrastructure, and to arrest 23-30 people among the Communist Party and KGB leadership. The rebels claimed that antisemitism was a state policy and planned to execute 70 Soviet party leaders and Soviet officials at the Union level. They strove to create a new multi-party political system that would help shape a democratic nationalities policy in the Soviet Union (HDA SBU, 16/1/985/263-69). Although the surveillance and arrests of the transgressors were conducted secretly, the Kharkiv community of writers were aware of the KGB operation. Many were subjected to scrutiny and were invited to KGB headquarters for questioning. KGB operatives were fishing for information and encouraging Jews to denounce Russians and Ukrainians and vice versa. At the same time, these conversations served two other purposes-possible recruitment and intimidation. As a KGB officer has argued, it was remarkably easy to recruit a Soviet citizen whose dependent status facilitated the task (Usol'tsev, qtd. in Nikash; Kasha).

Typically, the KGB sent a written invitation to the writer's home address. The time of the appointment was not discussed; it was assigned. KGB officers also informed writers by phone about the upcoming meeting. In special cases, they appeared at the writer's doorstep unannounced and took him or

\footnotetext{
36 For a discussion about the influence of Ukrainian culture and history on Chichibabin, see Dziuba; Peleshenko; for a discussion on the Drobyts'kyi Iar, see Skorobohatov 74-76; Kovba and Korohods'kyi 189-90. According to these authors, approximately 12,000 Kharkiv Jews were exterminated there, although the precise number killed is unknown.
} 
her immediately to Chernyshevs'kyi Street for questioning. Frequently, the conversation began by accusing the writer of writing "anti-Soviet" poems and defending dissidents. Open threats to sentence the writer to the gulag was part of the routine. For instance, the Kharkiv KGB operative Babusenko, who threatened to put Altunian in prison (Babusenko kept his word, of course), employed the same strategies in conversation with Rakhlina and Chichibabin (Rakhlin 140-41).

Sadly, many writers surrendered their friendships and bonds in the face of the real danger of imprisonment, especially from 1972-73, a period of vicious attacks against dissidents, Ukrainian nationalists, and Zionists. In Kharkiv and at the national level, many men and women were imprisoned and sent to detention camps. People like Rakhlina and Chichibabin were intimidated and ostracized. On the KGB's orders, they were denied publications. A "New Freeze" began in literature (CIA Archive, "A New Freeze" 48). In 1973, Chichibabin was expelled from the Writers' Union for distributing his poems through "samvydav" and for the public reading of his poem about Aleksandr Tvardovskii's (1910-71) secret funeral ("vorovskie pokhorony"). What preceded the reading was an invitation from the poetry section of the Writers' Union, chaired by Kats, to Chichibabin to read his poems. It would be difficult to establish whose idea it was to invite Chichibabin. Perhaps the KGB offered Kats the opportunity to finally uncover "antisovetchik" Chichibabin, who could not help himself-he always read the most "dangerous" poems in front of any audience. On January 9, 1973 (Chichibabin's 50th birthday), he read his seditious poems, which were recorded. At the Union's meeting, when its members discussed Chichibabin's behaviour, Kats was the most vocal accuser. The only writer who supported Chichibabin was Lev Boleslavskii (1935-2013), but his voice was lost in the chorus of perturbed literati (Rakhlin 128). The Kharkiv chapter voted almost unanimously to excommunicate Chichibabin; there were two abstentionsTret'iakov and Boleslavskii. Privately, Hel'fandbein told Feliks Rakhlin, Marlena Rakhlina's brother, that Chichibabin was a fool: "Who would allow this and forgive him these poems?" (Rakhlin 129).

On the same day, the Writers' Union also got rid of another member, the Ukrainian poet Vasyl' Borovyi (1923-2014). A former political prisoner, like Chichibabin, Borovyi inspired no trust among KGB officers and the "obkom" functionaries (Karas'-Chichibabina 137-38; Shelkovyi; Borovyi). Feliks Krivin (1928-2016), a writer from Uzhhorod (later a citizen of Israel), has noted with bitter irony that a new category of writers emerged in the 1970 - former members of the Writers' Union who were expelled as 
dissidents all over Ukraine, an identification that became no less honourable than membership in the Union (151). ${ }^{37}$

The KGB operations designed to curtail the nationalist and dissident movements in Ukraine and to disrupt the unity of the diverse but cohesive community of intellectuals were implemented until Gorbachev's perestroika, in some cases until the very end of the Soviet Union. ${ }^{38} \mathrm{KGB}$ active measures never managed to segregate the writers along ethnic or social lines, although the psychological consequences of KGB pressure for some writers were disastrous. State violence drove some of them into depression and anomie. ${ }^{39}$

\section{EPILOGUE}

Individual and collective reactions of writers to Kharkiv city politics in the 1960s-70s illuminated behaviours that contrast with what has been described by urban sociologists such as Georg Simmel, Robert Park and others, Edward Banfield and James Wilson (48-53), and Louis Wirth. For these scholars, a large city, and especially its political space, was a hostile environment that inevitably broke ties and bonds of even homogenous communities. In the Kharkiv case, the KGB's efforts were aimed at breaking the ties among the writers along ethnic lines, a strategy that would ensure state control over assertive nationalists in the Soviet republic. Studying Kharkiv's political space and how it shaped the writers' everyday lives offers

37 Both Chichibabin and Borovyi have always existed outside the Writers' Union as nationally and internationally recognized poets, and their membership in the Union has never enhanced their fame or influence as writers. Both left "official" literature in 1973 without any intention to return, but during perestroika in 1987 and 1990, respectively, their memberships in the Union were restored. The Union's invitation for Chichibabin to restore his membership was preceded by Ievtushenko's phone call to the Union's leadership in Kyiv. Bulat Okudzhava, Grigorii Pozhenian, Sergei Zalygin, and a group of writers from the editorial board of Novyi Mir sent telegrams to the Kharkiv chapter of the Writers' Union, demanding that its administration restore Chichibabin's membership. The Union's meeting occurred on October 30, 1987, and those who had excluded Chichibabin 14 years ago voted for his return.

${ }^{38}$ See photocopies of KGB reports to the Central Committee of the Communist Party of Ukraine from 1987 to 1991 in Shevchenko 441-811; and texts of KGB reports to the Central Committee of the Communist Party of Ukraine from 1960 to 1990 in Vasyl' Danylenko.

39 The French sociologist Emile Durkheim coined the term "anomie" to describe the condition that prevails when a person's belief system is ruined and his/her social norms and values have disintegrated. Anomie leads to social uncertainty, instability, and impersonality (a result of the pernicious impact of certain political, social, and economic environments). 
an opportunity to generalize about Soviet political culture and the cultural politics promoted by the Soviets in Ukraine during the period of reStalinization in the 1960s-70s. The social trends and communication patterns among the literary elites that were shaped by Kharkiv city politics are particularly interesting, as the members of this group were typically associated with independent thinking and the possession of creative minds, factors that complicated and challenged the tactics and strategies of those in power.

As we have seen, these factors, augmented by the Khrushchev Thaw, led to a conflict between the authorities and the intelligentsia, whose approaches to differences in ethnicity, nationality, and identity varied dramatically. For the local authorities, such differences served as a method of control and regimentation; for the literati, these differences were associated with diverse literary innovations and views that expanded the national spaces in Kharkiv. Jewish space was extended through translations of Yiddish texts into Ukrainian and Russian, and Russian-Ukrainian intellectual exchanges were expanded through mutual translations, shared intellectual affinities, and shared interests. The consistency and fluidity of inter-ethnic rituals and practices aggravated KGB operatives who sought to understand the logic behind the writers' gatherings and the literary uses of languages that, in the KGB's view, were inconsistent with the writers' cultural backgrounds. Ethnic Russians adopted Ukrainian as their literary language and vice versa. Either scenario was regarded with suspicion by the KGB (Kasha). The adoption of the Russian language by an ethnic Ukrainian may have suggested a move for self-preservation and careerism, while the adoption of the Ukrainian language by an ethnic Russian was seen as a sign of a nationalistic identity and an affinity for Ukrainian national culture (Adamovich 124-25).

The fluid identities and literary languages adopted by the writers were shaped by the multi-ethnic spatial specificity of the place, but the most interesting question is: how did the writers themselves conceptualize this fluidity and how did it shape their behavioural patterns? Tret'iakov and Muratov, for instance, knew full well that such fluidity was fraught with danger, yet they translated works written by Levina in Yiddish, a language that was doomed and banned in the Soviet Union. In the KGB's view, this was a political statement, as was the literary language Tret'iakov and Muratov, an ethnic Russian and an ethnic Jew, chose. Their use of the Ukrainian language provoked suspicion and harassment by the KGB in the atmosphere of state struggle against Ukrainian nationalism in the UkrSSR (interview with Tret'iakov, 17 June 1996; interview with Tret'iakova, 19 July 2005).

A subconscious freedom of self-expression, fostered by the Khrushchev Thaw, encouraged Kharkiv writers to behave quite the opposite of what was expected of them. They were unable to publish an uncensored text, and that 
was the only realm in which the writers conformed. In every other aspect of their daily lives, they transgressed, ignoring non-subtle suggestions of Communist Party functionaries and KGB operatives to "stay away from the Jews" or "to avoid Ukrainians" (Kasha). Often being drunk and expressing too much of what was considered an anti-Soviet and nationalist heresy, the writers were uncontrollable and inconvenient for the authorities (Romanovs'kyi 62, 65). Dobrovol'skii and Tret'iakov, Bondar and Vadim Levin, Chichibabin and Hel'fandbein-people of various cultural backgrounds - wanted not to co-exist, as the KGB suggested, but to co-create and share their experiences, thoughts, and poetry.

Traversing ethnic boundaries erected by the KGB did not appear to be a political statement for them (they were quite aware of the consequences of such behaviour), but rather an everyday practice performed for purely aesthetic and humane reasons. Paradoxically, living apolitically in the realm of poetry was nevertheless a political choice. It was their freedom of aesthetic choice that became a political problem for the KGB because quite a few of them, like Motrich, lived without noticing the existence of Soviet power.

The majority of writers certainly suffered from intellectual constraints enforced by censorship, having to accept the domination of state power over their professional lives. Locked in silent combat with the state and intoxicated with alcohol, the writers were captivated by shared practices that helped them experience an apolitical Kharkiv, rituals that they repeated almost daily that allowed them to escape from the space of violence (Miloslavskii; Shatylov; Briuhhen [Briuggen], Bloknoty 73). Saturated with literature, their communal and private lives belonged to them, or so they thought.

As in any other Soviet institution or association, there were individuals in the Writers' Union who collaborated with the KGB, denouncing people like Rakhlina, Chichibabin, and Bogoslavskii. ${ }^{40}$ It is difficult to say whether they did it out of fear of the KGB, concern for their families, professional jealousy, antisemitism, or to preserve or advance their careers; all these reasons seem legitimate and possible. Non-collaborators were haunted by the thought that their talents and minds might disintegrate under the pressure of the KGB or that they would be forced to betray their fellow colleagues. As intellectuals, they were obsessed not with survival per se but with the words that helped them survive. They could easily become victims or beneficiaries of the language they used publicly or in private settings. By 1972, they realized that

\footnotetext{
40 To many writers, Kotliarov seemed to be one of them. Kotliarov's name was codified in one of Chichibabin's poems (quoted in Rakhlin 69). According to Leonid Khait (1928-2017), another Kharkiv writer, Arkadii Shkol'nik, denounced and helped the KGB arrest at least a dozen of his colleagues.
} 
privacy and constant ideological self-monitoring were unrealistic, and probably unattainable.

More than thirty years ago, Jaroslaw Bilocerkowycz argued that of two models of reaction to state violence among Ukraine's intellectuals and dissidents-the disillusionment model and the suspicions-confirmed model-east Ukrainians were most prone to the former (191). Indeed, by the early 1970s, Kharkiv writers were disillusioned, perceiving their dependent status as a shared tragedy. This tragic perception generated friendships, bonds, and literature that shaped their ways of life ("sposib zhyttia") until their last days (Briuhhen, "Ia rozumiiu"). Regardless of the writers' literary language and cultural backgrounds, they reached out to each other in hope of professional advice, support, and protection. Mark Cherniakov (years of life are unknown), Hel'fandbein, and Muratov instantly sensed the birth of an extremely gifted poet in Rakhlina, and on several occasions Muratov recommended the Writers' Union grant Rakhlina membership, which never happened (Rakhlin 9). Galkin and Kats enthusiastically welcomed Tret'iakov to the Kharkiv chapter, who at the age of twenty-two became a Kyiv celebrity, a journalist, and a member of the 1960s generation, willing to relocate to Kharkiv after graduating from Taras Shevchenko National University of Kyiv (LTPA 1957). These examples of support are numerous, revealing the emergence of a distinct community of people, durable and resistant to the ethnic politics of the 1960s-70s.

Indeed, ethnic conflicts in the professional and private space of the Kharkiv writers in this era were a rarity. As theatre director Starodub has suggested, "we were raised as internationalists. I look at this woman, and see not a Jew but a talented beauty." Jews fell in love with Ukrainians and with Russians, and vice versa. For instance, the Ukrainian poet Iurii Herasymenko (1927-85) was infatuated with Rakhlina and, trying to win her heart, was bringing her huge bouquets of fresh lilac flowers (Rakhlin 9). The muses of Limonov, Chichibabin, and Dobrovol'skii were Jewish women, extremely protective of their husbands' literary talents. These personal relationships help us recognize that the Kharkiv space was not only multi-ethnic and multicultural, it was also multi-faceted and polyhedral, a space where Gaston Bachelard's metaphor "poetics of space" gains real, romantic, and historical contours.

As many scholars have suggested, people's attachments to a place, its politics, and its myriad of emotionally charged ties and connections shape their habits, practices, and identities. Similarly, they change this place through their imaginations, practices, and rituals (Tuan; Musiiezdov 280; Zaharchenko). As a result of these exchanges, the place becomes less opaque, acquiring an identity of its own (Banfield and Wilson 60). In the 1960s and 1970 s, after a brief period of de-Stalinization, Kharkiv once again became a place of danger for various ethnic groups, especially for Ukrainians and Jews, 
and in this light it was an archetypical Ukrainian city with its formal and informal practices and a dangerous "mix of integrative and disintegrative forces" and "balanced pressures of conflict and attachment" (Banfield and Wilson 60).

The KGB's covert divide and conquer strategies encouraged the Kharkiv literati to stick to the Leninist internationalist ideology that shaped their regional supranational identities and beliefs. Negating ethnic stereotypes forced on them, and seeking redemption in national culture, art, and creativity, they adopted two other identities, Soviet and national, establishing the foundations for post-Soviet modern Kharkiv that still remains Soviet in many ways (Kravchenko, "Kharkiv: A Borderland City" 250; Westrate).

Ethnicity and politics are related, and their meanings are determined by the place where they are observed. As one philosopher has argued, "place is an organized world of meaning" (Tuan 179). At different times, the Soviet politics in Ukraine impregnated the notion of ethnicity with various meanings. Crucially, it made people aware of the consequences of these manipulations. The writers estranged themselves from these manipulations and focused on what they knew and loved the most-literature (interview with Pererva, 17 July 2017; LTPA, 30 March, 1957).

Clearly, at no time, no matter what their ethnicity, were writers trusted by the authorities. The 1960s and re-Stalinization brought the Jewish and Ukrainian questions again to the surface. Jews imagined a new Holocaust happening in Ukraine; Ukrainians experienced a new wave of state terror. Possibly unconsciously, they created a community that might have withstood state pressures. Moreover, through people like Bondar, who shared his experiences in the Nazi camps with the younger generation of poets, the continuity and distribution of historical knowledge occurred, which made the writers acutely aware of the horrors of the Holocaust and their shared history. These discussions provided a space for Kharkiv literati where the process of healing from post-war tragedies and Soviet divisiveness began.

Most importantly, despite their fear of the authorities, their inadequacies, their behavioural inconsistencies, and their conformism, the writers' post-Khrushchev Thaw romanticism and optimism facilitated the emergence of a new literature and a new literary community that placed Kharkiv on the map of world literature, offering readers not its truncated ethnic image but an image of a place where various ethnic groups could reside and co-create without major conflicts and strife.

British philosopher Aldous Huxley posited that we can gather and analyze information about people's experiences, but never their actual experiences. Even when people share with us their sensations, feelings, and insights, they are far from being accurate, because sensations, feelings, and 
insights are incommunicable (Huxley 12). Huxley was convinced that "from family to nation, every human group is a society of island universes," where suffering and joy are experienced in solitude (13). The case of intellectuals is even more complicated because their minds are their own places, where they reside, contemplating the surroundings: "the places inhabited by ... the exceptionally gifted are so different from the places where ordinary men and women live, that there is little or no common ground of memory to serve as a basis for understanding of fellow feeling. Words are uttered but fail to enlighten" (Huxley 13). Keeping faith with Huxley's suggestion, this narrative offers only a glimpse into the Kharkiv writers' lives during reStalinization, a period when they seemed to lose their interest in Kharkiv as a place of opportunities and cultural and intellectual freedom, regaining faith in its cultural potential only during perestroika and the post-Soviet era. Under terror, they withdrew from political identification, trying to preserve their humanity, integrity, and literary talent. They experienced a perpetual crisis of identity, which Huxley would describe as "one continually changing apocalypse" (21). Chronic intellectual abuse and assault on their national culture and pride prepared most writers for living in a space of silence for an indefinite duration. A sense of community, complementarity of interests, and a shared attachment to Kharkiv and their past let people like Briuhhen and Tret'iakov, Chichibabin and Rakhlina, rejuvenate their authentic voices and continue to write. 
Works Cited

Abramson, Henry. A Prayer for the Government: Ukrainians and Jews in Revolutionary Times, 1917-1920. Harvard UP, 1999.

Adamovich, Anthony. "The Non-Russians." Soviet Literature in the Sixties, edited by Max Hayward and Edward L. Crowley, Methuen, 1965, pp. 100-29.

"Aleksandr Cherevchenko." Russkaia poeziia, http://www.yazemlyak.ru/avtpoesia.asp?id_avt=734. Accessed 27 Dec. 2019.

Altunian, Genrikh (Henrikh Altunian). Tsena svobody: Vospominaniia dissidenta. Folio, 2000.

Amar, Tarik Cyril. The Paradox of Ukrainian Lviv: A Borderland City between Stalinists, Nazis, and Nationalists. Cornell UP, 2015.

Aster, Howard, and Peter J. Potichnyj. Jewish-Ukrainian Relations: Two Solitudes. Mosaic Press, 1983.

Bachelard, Gaston. The Poetics of Space: The Classic Look at How We Experience Intimate Places. Translated by Maria Jolas, Beacon Press, 1994.

Banfield, Edward C., and James Q. Wilson. City Politics. Vintage Books, 1963.

Bartal, Israel, and Antony Polonsky, editors. Focusing on Galicia: Jews, Poles, and Ukrainians, 1772-1918. The Littman Library of Jewish Civilization, 1999. Polin: Studies in Polish Jewry 12.

Bartov, Omer. Anatomy of a Genocide: The Life and Death of a Town Called Buczacz. Simon \& Schuster, 2019.

Beliaev, Konstantin, and Andrei Krasniashchikh. Khar'kov v zerkale mirovoi literatury. Folio, 2007.

Bellezza, Simone A. "Wings to Lift the Truth Up High: The Role of Language for the Shistdesiatnyky." Harvard Ukrainian Studies, vol. 35, nos. 1-4, 2017-18, pp. 21332.

Benifand, Alexander. "Jewish Emigration from the USSR in the 1990s." Innovation in Social Sciences Research, vol. 4, nos. 3-4, 1999, pp. 35-51.

Berezhnaya, Liliya. "A View from the Edge: Borderland Studies and Ukraine, 19912013." The Future of the Past: New Perspectives on Ukrainian History, edited by Serhii Plokhy, HURI/Harvard UP, 2016, pp. 43-68.

Bertelsen, Olga. "The House of Writers in Ukraine, the 1930s: Conceived, Lived, Perceived." Carl Beck Papers, no. 2302, 2013, pp. 4-72.

---. "Political Affinities and Maneuvering of Soviet Political Elites: Heorhii Shevel and Ukraine's Ministry of Strange Affairs in the 1970s." Nationalities Papers: The Journal of Nationalism and Ethnicity, vol. 47, no. 3, 2019, pp. 394-411. DOI: $10.1017 / \mathrm{nps} .2018 .51$

---. "Shistdesiatnyky: Robert Tret'iakov." Literaturna Ukraina, no. 7, 25 Feb. 2016, pp. 6-7.

Bilenky, Serhiy. Imperial Urbanism in the Borderlands: Kyiv, 1800-1905. Toronto UP, 2018.

---. Romantic Nationalism in Eastern Europe: Russian, Polish, and Ukrainian Political Imaginations. Stanford UP, 2012.

Bilocerkowycz, Jaroslaw. Soviet Ukrainian Dissent: A Study of Political Alienation. Westview Press, 1988. 
Bitov, Andrei. "Pisatel' sam ne p'et, no ego geroi kak poddadut—tak emu v golovu otdaet." Interview by Marina Grineva, Moskovskie novosti, 21 Oct. 2011, http://www.mn.ru/friday/74757. Accessed 14 Sept. 2019.

Bondarenko, Olena. "23 kvitnia 1920 narodyvsia ukrains'kyi pys'mennyk Hryhorii Tiutiunnyk." Ridna kraina: svitohliadnyi portal, 23 Apr. 2019, https://ridna.ua/2019/04/23-kvitnya-1920-roku-narodyvsya-ukrajinskyipysmennyk-hryhorij-tyutyunnyk/. Accessed 14 Sept. 2019.

Borovyi, Vasyl'. "'Mene blahoslovyv do druku Svidzins'kyi."' Interview by Liutsyna Khvorost and Larysa Vyrovets', Redaktor i poetesa Liutsyna Khvorost, 14 Mar. 2012, https://dobrolucina.wordpress.com/2012/03/14/василь-боровиймене-благословив-до-д/. Accessed 14 Sept. 2019.

Briuggen, Vladimir (Volodymyr Briuhhen). Bloknoty: Kniga tret'ia. Maidan, 2010.

---. "Ia rozumiiu literaturu peredusim iak sposib zhyttia." Interview by Ievhen Baran, Khar'kov-350: Gumanitarnye http://kharkovhumanit.narod.ru/Liki_kult.html. Accessed 7 Sept. 2017.

Brusilovskii, Anatolii. Studiia. Official Site of Anatolii Brusilovskii. https://www.unvergessliche-augenblicke.com/download/studija.pdf. Accessed 30 Aug. 2017.

Bushin, Vladimir. Ia zhyl vo vremena Sovetov. Dnevniki. Algoritm, 2014.

Casula, Philipp. “Russia's and Europe's Borderlands: Between Sovereign Intervention and Security Management." Problems of Post-Communism, vol. 61, no. 6, 2014, pp. 6-17. DOI: 10.2753/PPC1075-8216610601

Cherevchenko, Aleksandr. "Bunt bessmyslennyi i besposhchadnyi?" Press Latviia, 8 Feb. 2014, http://press.lv/post/bunt-bessmyslennyj-i-besposhhadnyj/. Accessed 24 June 2019.

---. “Druz'ia davno minuvshikh let.” Relga, no. 18 (120), 16 Nov. 2005, http://www.relga.ru/Environ/WebObjects/tgu-

www.woa/wa/Main?textid=665\&level1=main\&level2=articles. Accessed 14 Sept. 2019.

---. Koleso. Prapor, 1966.

---. “Trava zabveniia." Imhoclub.LV, 17 Aug. 2014, https://imhoclub.lv/ru/material/trava_zabvenija. Accessed 24 June 2019.

Chichibabin, Boris. "'Da budet volia tvoia, a ne moia, gospodi...'” Interview by Svetlana Dudar', Official Site of Boris Alekseevich Chichibabin, 1993, http://chichibabin.narod.ru/interview.html. Accessed 14 Sept. 2019.

---. Stikhotvoreniia. TO Ekskliuziv, 2003.

Conquest, Robert. We and They. Civic and Despotic Cultures. Temple Smith, 1980.

Danylenko, Vasyl', editor. Politychni protesty i inakodumstvo v Ukraini (1960-1990). Smoloskyp, 2013.

Danylenko, Viktor. "Politychni zminy v SRSR i Ukraini v period 'khrushchovs'koi' vidlyhy." Ukraina XX st.: Kul'tura, ideolohiia, polityka, no. 14, 2008, pp. 3-17. Available on-line at http://history.org.ua/JournALL/xxx/14/1.pdf. Accessed 3 Sept. 2014.

Dekel-Chen, Jonathan, et al., editors. Anti-Jewish Violence: Rethinking the Pogrom in East European History. Indiana UP, 2010.

Durkheim, Emile. Suicide: A Study in Sociology. Edited by George Simpson, translated by John A. Spaulding and George Simpson, Routledge \& Kegan Paul, 1968. 
Dziuba, Ivan. "Slovo sovisne i dobre." Vsemu zhivomu ne chuzhoi: Boris Chichibabin v stat'iakh i vospominaniiakh, edited by M. I. Bogoslavskii, et al., Folio, 1998, pp. 200-208.

Estraikh, Gennady. Yiddish in the Cold War. Routledge, 2008. Legenda Studies in Yiddish 7.

Filatov, Arkadii. "Khrani tebia gospod'." Interview by Nikolai Artamonov, Khar'kov350: Gumanitarnye resursy, http://kharkovhumanit.narod.ru/Intervu.html. Accessed 14 Sept. 2019.

---. "Vdogonku." Chichibabin.narod.ru, 1995, http://chichibabin.narod.ru/filatov.html. Accessed 5 Aug. 2017.

Fowler, Mayhill. "Yiddish Theater in Soviet Ukraine: Reevaluating Ukrainian-Jewish Relations in the Arts." $A b$ Imperio, no. 3, 2011, pp. 167-88. DOI: 10.1353/imp.2011.0096

Garrard, John, and Carol Garrard. Inside the Soviet Writers' Union. The Free Press, 1990.

Gilley, Cristopher. "Beyond Petliura: The Ukrainian National Movement and the 1919 Pogroms." East European Jewish Affairs, vol. 47, no. 1, 2017, pp. 45-61. DOI: 10.1080/13501674.2017.1306403b

Goble, Paul A. "Readers, Writers, and Republics: The Structural Basis of Non-Russian Literary Politics." The Nationalities Factors in Soviet Politics and Society, edited by Lubomyr Hajda and Mark Beissinger, Westview Press, 1990, pp. 131-47.

Grigorenko, Petro G. Memoirs. Translated by Thomas P. Whitney, W.W. Norton, 1982.

Heiman, Leo. "Ukrainians and the Jews." Ukrainians and Jews: A Symposium. The Ukrainian Congress Committee of America, 1966, pp. 57-64.

Hel', Ivan. Vyklyk systemi: Ukrains'kyi vyzvol'nyi rukh druhoi polovyny XX stolittia. Edited by Iryna Iezers'ka, Chasopys, 2013.

Himka, John-Paul. "Interventions: Challenging the Myths of Twentieth-Century Ukrainian History." Convolutions of Historical Politics, edited by Alexei Miller and Maria Lipman, CEU P, 2012, pp. 211-38.

---. "The Lviv Pogrom of 1941: The Germans, Ukrainian Nationalists, and the Carnival Crowd." Canadian Slavonic Papers, vol. 53, nos. 2-4, 2011, pp. 209-43. DOI: 10.1080/00085006.2011.11092673

---. "Ukrainian Memories of the Holocaust: The Destruction of Jews as Reflected in Memoirs Collected in 1947." Canadian Slavonic Papers, vol. 54, nos. 3-4, 2012, pp. 427-42. DOI: 10.1080/00085006.2012.11092716

Horyn', Bohdan. Ne til'ky pro sebe: Knyha druha (1965-1985). Pul'sary, 2008.

Hunczak, Taras. Simon Petliura and the Jews: A Reappraisal. Ukrainian Historical Association, 2008.

Huxley, Aldous. The Doors of Perception. Perennial Library, 1970.

Iarova, V. S. "Shevchenkivs'ka tema v drukovanii hrafitsi Kharkova 1960-kh rokiv." Visnyk Lvivs'koi natsional'noi akademii mystetstv, no. 25, 2014, pp. 228-37.

"Ievtushenko i Khar'kov." Khar'kovskiie Izvestiia, 7 Apr. 2017, http://izvestia.kharkov.ua/on-line/18/1237277.html. Accessed 24 June 2019.

"Iosif Gol'denberg." Sviaz' vremen, http://www.thetimejoint.com/taxonomy/term/3893. Accessed 22 July 2017. 
Kalynychenko, Volodymyr. "Volodymyr Pasichnyk-poet-protestant, borets'orhanizator." Zona, edited by Oleksa Riznykiv, no. 27, Simeks-prynt, 2011, pp. 126-34.

Kappeler, Andreas. "From an Ethnonational to a Multiethnic to a Transnational Ukrainian History." A Laboratory of Transnational History: Ukraine and Recent Ukrainian Historiography, edited by Georgiy Kasianov and Philipp Ther, CEU P, 2009, pp. 51-80.

Karas'-Chichibabina, Liliia. "Ty i sama b do smerti ne zabyla." Vsemu zhivomu ne chuzhoi: Boris Chichibabin $v$ stat'iakh $i$ vospominaniiakh, edited by M. I. Bogoslavskii, et al., Folio, 1998, pp. 127-48.

Kas'ianov, Heorhii. Nezhodni: Ukrains'ka intelihentsiia v rusi oporu 1960-80-kh rokiv. Lybid', 1995.

Khait, Leonid. Prisoedinilis' $k$ bol'shinstvu: Ustnye rasskazy Leonida Khaita, zanesennye na bumagu. Mannsohn House, 2007.

Kolstø, Pål. "Faulted for the Wrong Reasons: Soviet Institutionalization of Ethnic Diversity and Western (Mis)interpretations." Institutional Legacies of Communism: Change and Continuities in Minority Protection, edited by Karl Cordell, et al., Routledge, 2013, pp. 31-44.

Kotkin, Stephen. Magnetic Mountain: Stalinism as a Civilization. U of California P, 1995.

Kotliarov, Boris. "Moemu gorodu." Kharkiv, pisne moia, edited by Iurii Stadnychenko, Vydavnytstvo "Prapor," 1982, pp. 91-92.

Kovba, Zh., and Iu. Korohods'kyi. "Ievrei Ukrainy pid chas Druhoi svitovoi viiny: Holokost ta Opir." Narysy z istorii ta kul'tury ievreiv Ukrainy, edited by Leonid Finberg and Volodymyr Liubchenko, Dukh i litera, 2008, pp. 182-205.

Kravchenko, Volodymyr. "Kharkiv: A Borderland City." Cities after the Fall of Communism: Reshaping Cultural Landscape and European Identity, edited by John Czapliska, et al., Woodrow Wilson Center Press and Johns Hopkins UP, 2009, pp. 219-53.

---. Khar'kov/Kharkiv: Stolitsa pogranich'ia. European Humanities University P, 2010.

Krivin, Feliks. “Druz'ia moi, prekrasen nash soiuz!” Vsemu zhyvomu ne chuzhoi: Boris Chichibabin v stat'iakh $i$ vospominaniiakh, edited by M. I. Bogoslavskii, et al., Folio, 1998, pp. 151-59.

Kryvenchuk, Valentyna. "Stanislav Shumyts'kyi ta ioho seredovyshche." Veb-portal mista Liubotyna, 20 Mar. 2015, http://lubotin.kharkov.ua/main/5669-do-dnyanarodzhennya-s-shumickogo.html. Accessed 14 Sept. 2019.

Kuzio, Taras. Putin's War against Ukraine: Revolution, Nationalism, and Crime. University of Toronto, CreateSpace, 2017.

---. "The Soviet Roots of Anti-Fascism and Antisemitism." New Eastern Europe, no. 6, 2016, pp. 93-100.

Lahoza, Viktor. "Zemliaky-kharkiv"'iany." Kharkiv, pisne moia, edited by Iurii Stadnychenko, Vydavnytstvo "Prapor," 1982, pp. 95-96.

Lefebvre, Henri. The Production of Space. Translated by Donald Nicholson-Smith, Blackwell Publishing, 1991.

Leibfreid, A. I., and I. I. Poliakova. Khar'kov: Ot kreposti do stolitsy. Folio, 1998.

Levina, Khana. Ridne. Prapor, 1967.

Levin, Vadim. Kuda uekhal tsirk. Folio, 2001. 
Liber, George 0. Total Wars and the Making of Modern Ukraine, 1914-1954. Toronto UP, 2016.

Limonov, Eduard. Molodoi negodiai. Zhurnal “Glagol,” 1992.

Lotman, Iu. M. Stat'i po semiotike kul'tury i iskusstva. Edited by R. G. Grigor'eva, Akademicheskii proekt, 2002.

Magocsi, Paul Robert, and Yohanan Petrovsky-Shtern. Jews and Ukrainians: A Millennium of Co-Existence. Toronto UP, 2016.

Malpas, J. E. Place and Experience: A Philosophical Topography. Cambridge UP, 2007.

Medvedeva, Galina. “'Sushchestvovan'ia svetloe usilie' (Iulii Daniel').” Znamia, no. 2, 2001, pp. 159-69.

Mel'nykiv, Rostyslav. Literaturni 1920-ti: Postati (Narysy, obrazky, etiudy). Maidan, 2013.

Miloslavskii, Iurii. "Stremlius' k otchetlivosti..." Interview by Dmitrii Bavil'skii, Chastnyi Korrespondent, 1 Apr. http://www.chaskor.ru/article/yurij_miloslavskij_stremlyus_k_otchetlivosti_2 2852\&ext=subscribe. . Accessed 14 Sept. 2019.

Motyl, Alexander J. Dilemmas of Independence: Ukraine after Totalitarianism. Council on Foreign Relations Press, 1993.

Musiezdov, A. A. Sotsiologicheskaia kontseptsiia gorodskoi identichnosti. KhNU imeni V. N. Karazina, 2013.

Mykhailyn, Ihor. Literaturna Kharkivshchyna. Poeziia. Maidan, 2007.

---. "Poet v optytsi svoho chasu." Interview by Ivan Perepeliak, Kharkivs'ka oblasna orhanizatsiia: Natsional'na spilka pys'mennykiv Ukrainy, 1 Nov. 2013, https://kharkiv-nspu.org.ua/archives/2644. Accessed 14 Sept. 2019.

Nikash, B. "Simbioz. KGB i ievrei” (excerpts from Vladimir Usol'tsev). LiveJournal, 31 July 2007. https://duel-gazeta.livejournal.com/97147.html. Accessed 11 Jan. 2020.

Omel'chenko, Vasilii. Smutnye gody (zapiski ochevidtsa). Maidan, 2013.

---. "Tam zhili poety..." Prostranstvo literatury, 11 Dec. 2013, pp. 199-205. Available on-line: https://www.kpi.kharkov.ua/archive/Conferences/. Accessed 14 Sept. 2019.

Orlov, Vitalii. “Akh, Zhenia, Zhenia, Zhenechka, s nim sluchai byl takoi...” Elegant New York, 27 Jan. 2017, http://elegantnewyork.com/evtushenko-orlov/. Accessed 14 Sept. 2019.

Park, Robert E., et al. The City: Suggestions for Investigation of Human Behavior in the Urban Environment. Chicago UP, 1984.

Peleshenko, Nataliia. "Dukhovnyi podvyh kniaziv Borysa i Hliba v ukrains'kii literaturi XX st. (na materiali poezii Borysa Chychybabina)." Sviati Borys i Hlib u natsional'nii kul'turi ta suspil'nii dumtsi: dosvid 1000-richnoi prysutnosti v ukrains'kii istorii. Zbirnyk naukovykh statei, Akta, 2016, pp. 124-43. Available online:

http://ekmair.ukma.edu.ua/bitstream/handle/123456789/11556/Peleshenk o_Dukhovnyi_podvyh_kniaziv.pdf?sequence=1\&isAllowed=y. Accessed 5 Aug. 2017.

Pererva, Anatolii, editor. Natsional'na spilka pys'mennykiv Ukrainy: 75 rokiv. Maidan, 2009. 
Petrovsky-Shtern, Yohanan. The Anti-Imperial Choice: The Making of the Ukrainian Jew. Yale UP, 2009.

---. "The Art of Shifting Contexts." Harvard Ukrainian Studies, vol. 34, nos. 1-4, 201516, pp. 241-57.

---. "Jews in Ukrainian Thought: Between the 1940s and the 1990s." The Ukrainian Quarterly, vol. LX, nos. 3-4, 2004, pp. 231-70.

---. "Reconceptualizing the Alien: Jews in Modern Ukrainian Thought." Ab Imperio, no. 4, 2003, pp. 519-80. DOI: 10.1353/imp.2003.0055

Plokhy, Serhii. The Gates of Europe: A History of Ukraine. Basic Books, 2015.

---. Lost Kingdom: The Quest for Empire and the Making of the Russian Nation. Basic Books, 2017.

---. Unmaking Imperial Russia: Mykhailo Hrushevsky and the Writing of Ukrainian History. Toronto UP, 2005.

Ploticher, I. A. Slovo o rodnom gorode. 2nd ed., "Zolotye stranitsy," 2017.

Polons'kyi, Radii. "Nepoiasnymyi Robert." Vechernii Khar'kov, 18, 19, 21, 23, 24, 25 July 1998.

Poulet, Georges. Proustian Space. Translated by Elliot Coleman, John Hopkins UP, 1977.

Proust, Marcel. Remembrance of Things Past. Translated by C. K. Scott Moncrieff and Terence Kilmartin, vol. 1, 2, Vintage Books, 1981.

Prusin, Alexander Victor. Nationalizing a Borderland: War, Ethnicity, and Anti-Jewish Violence in East Galicia, 1914-1920. Alabama UP, 2005.

Radchenko, Yuri. "The Organization of Ukrainian Nationalists (Mel'nyk Faction) and the Holocaust: The Case of Ivan Iuriiv." Holocaust \& Genocide Studies, vol. 31, no. 2, 2017, pp. 215-39. DOI: 10.1093/hgs/dcx038

---. "Ukrainian Historiography of the Holocaust through the Prism of Modern Discourse on Collaboration in the Territory of Ukraine." Dapim: Studies on the Shoah, vol. 31, no. 3, 2017, pp. 313-21. DOI: 10.1080/23256249.2017.1402746

---. “'We Fired All Cartridges at Them': Ukrainische Hilfspolizei and the Holocaust on the Territory of the Generalbezirk Kharkiv, 1941-1943." Yad Vashem Studies, vol. 41, no. 1, 2013, pp. 63-98.

Rakhlina, Marlena. Chto bylo—vidali... "Prava liudyny," 2006.

Rakhlin, Feliks. O Borise Chichibabine i ego vremeni: Strochka iz zhizni. Folio, 2004.

Rakytians'ka, V. D., editor. Biblioteka v istorychnomu prostori triokh epokh. Do 125richchia Kharkivs'koi derzhavnoi naukovoi biblioteky im. V. H. Korolenka. RA "IRIS," 2011.

Redlich, Shimon. Together and Apart in Brzezany: Poles, Jews, and Ukrainians, 19191945. Indiana UP, 2002.

Reid, Anna. Borderland: A Journey Through the History of Ukraine. Basic Books, 1999.

Richardson, Tanya. Kaleidoscopic Odessa: History and Place in Contemporary Ukraine. Toronto UP, 2008.

Risch, William Jay. The Ukrainian West: Culture and the Fate of Empire in Soviet Lviv. Harvard UP, 2011.

Romanovs'kyi, V'iacheslav. Osiaiala natkhnenniam Slobozhan'. Vydavnytstvo Fedorko, 2013.

Rudenko, Raisa, editor. Mykola Rudenko: "Naibil'she dyvo-zhyttia." Spohady. Smoloskyp. 2013. 
Schuman, Tomas. Black Is Beautiful. Communism Is Not. Almanac, 1985.

Shanes, Joshua, and Yohanan Petrovsky-Shtern. "An Unlikely Alliance: The 1907 Ukrainian-Jewish Electoral Coalition." Nations and Nationalism, vol. 15, no. 3, 2009, pp. 483-505. DOI: 10.1111/j.1469-8129.2009.00381.x

Sharova, T. M. "Vasyl' Bondar: Osoblyvosti biohrafichnoi prozy ta ideino-khudozhni poshuky pys'mennyka." Visnyk Luhans'koho Natsional'noho Universytetu imeni Tarasa Shevchenka, vol. 3, no. 166, 2009, pp. 179-85.

Shatylov, Mykola. Kliati simdesiati... Na pam"iati stalo, na pam"iati staly, "Apostrof," 2011.

Shelkovyi, Serhii. "No On-to darom sroka ne daet..." Interview by Vasyl' Borovyi, Kharkivs'ka oblasna orhanizatsiia: Natsional'na spilka pys'mennykiv Ukrainy, 15 Nov. 2014, http://kharkiv-nspu.org.ua/archives/3444. Accessed 14 Sept. 2019.

Shevchenko, Oles', editor. Ukrains'ka Hel'sins'ka Spilka u spohadakh i dokumentakh. "Iaroslaviv Val," 2012.

Shtif, Nokhem. The Pogroms in Ukraine, 1918-19: Prelude to the Holocaust. Translated by Maurice Wolfthal, Open Book Publishers, 2019.

Simmel, Georg. Conflict: The Web of Group-Affiliations. Free Press, 1955.

Skorobohatov, Anatolii. Kharkiv u chasy nimets'koi okupatsii (1941-1943). Prapor, 2006.

Snyder, Timothy. Black Earth: The Holocaust as History and Warning. Tim Duggan Books, 2015.

---. Bloodlands: Europe between Hitler and Stalin. Basic Books, 2010.

---. Sketches from a Secret War: A Polish Artist's Mission to Liberate Soviet Ukraine. Yale UP, 2005.

Stadnychenko, Iurii, editor. Kharkiv, pisne moia. Vydavnytstvo "Prapor," 1982.

Sumtsov, M. F. Slobozhane: Istorychno-etnohrafichna rozvidka. Edited by Leonid Ushkalov, Vydavets' Rozhko S. H., 2017.

Sverstiuk, Ievhen. "My obraly zhyttia." Bunt pokolinnia: rozmovy z ukrains'kymy intelektualamy, complied and edited by Bogumyla Berdykhovs'ka and Olia Hnatiuk, translated by Roksana Kharchuk, Dukh i litera, 2004.

Taniuk, Les'. "V Bykovne lezhit i moi ded, izvestnyi kievskii iurist Nikolai Kenigsfest." Interview by Irina Lisnichenko, Fakty. 10 Oct. 2012, https://fakty.ua/153945les-tanyuk-v-bykovne-lezhit-i-moj-ded-izvestnyj-kievskij-yurist-nikolajkenigsfest. Accessed 14 Sept. 2019.

Tarnashyns'ka, Liudmyla. Ukrains'ke shistdesiatnytstvo: profili na tli pokolinnia (Istoryko-literaturnyi ta poetykal'nyi aspekty). Smoloskyp, 2010.

Ther, Philipp. "Regionalism and Border Studies in Modern Europe: The Case of Upper Silesia in Context." Studies on National Movements, no. 1, 2013, pp. 17-49.

Tillett, Lowell. The Great Friendship: Soviet Historians on the Non-Russian Nationalities. North Carolina UP, 1969.

Torbakov, Igor. "Ukraine and Russia: Entangled Histories, Contested Identities, and a War of Narratives." Revolution and War in Contemporary Ukraine: The Challenge of Change, edited by Olga Bertelsen, ibidem-Verlag and Columbia UP, 2017, pp. 89-119.

Tromly, Benjamin. "An Unlikely National Revival: Soviet Higher Learning and the Ukrainian 'Sixtiers,' 1953-1965.” Russian Review, vol. 68, no. 4, 2009, pp. 607-22. 
Tuan, Yi-Fu. Space and Place: The Perspective of Experience. 6th ed., Minnesota UP, 2008.

Vernik, Aleksandr. "Boris A. Chichibabin." The Blue Lagoon: Anthology of Modern Russian Poetry, edited by Konstantin Kuzminsky and Grigorii Kovalev, Oriental Research Partners, 1982.

Von Hagen, Mark. "States, Nations, and Identities: The Russian-Ukrainian Encounter in the First Half of the Twentieth Century." Culture, Nation, and Identity: The Ukrainian-Russian Encounter (1600-1945), edited by Andreas Kapeller et al., CIUS P, 2003.

Vysheslavskii, Leonid. "V al'bom muzeia KhTZ." Kharkiv, pisne moia, edited by Iurii Stadnychenko, Vydavnytstvo "Prapor," 1982, pp. 157-58.

Westrate, Michael T. Living Soviet in Ukraine from Stalin to Maidan: Under the Falling Red Star in Kharkiv. Lexington Books, 2016.

Wirth, Louis. "Urbanism as a Way of Life." American Journal of Sociology, vol. 44, no. 1, 1938, pp. 1-24.

Wolff, Larry. The Idea of Galicia: History and Fantasy in Habsburg Political Culture. Stanford UP, 2010.

Yekelchyk, Serhy. "The Early 1960s as a Cultural Space: A Microhistory of Ukraine's Generation of Cultural Rebels." Nationalities Papers, vol. 43, no. 1, 2015, pp. 4562. DOI: $10.1080 / 00905992.2014 .954103$

Zaharchenko, Tanya. Where Currents Meet: Frontiers in Post-Soviet Fiction of Kharkiv, Ukraine. CEU Press, 2016.

Zaitsev, B. P., et al., editors. Kharkiv: Zbirnyk arkhivnykh dokumentiv i materialiv. Vydavnytstvo NUVS, 2004.

Zakharkov, Ievhen. "Iak reformuvaty sudovu systemu." Interview by Mykola Kniazhyts'kyi, Espreso, 24 July 2016, http://espreso.tv/article/2016/07/24/zakharov. Accessed 14 Sept. 2019.

Zeltser, Arkadi. "Jewish Response to the Non-Jewish Question: 'Where Were the Jews during the Fighting?' 1941-45." East European Jewish Affairs, vol. 46, no. 1, 2016, pp. 4-25. DOI: 10.1080/13501674.2016.1144137

Zhabotinskii (Zeev), Vladimir. "O ievreiakh i russkoi literature" (an excerpt from Izbrannoe). YouTube, uploaded by Mikhail Pol'skii, 4 May 2019, https://www.youtube.com/watch?v=Li-I0NWdHp0. Accessed 11 January 2020.

Zhylenko, Iryna. Homo Feriens: Spohady. Smoloskyp, 2011.

Zinkevych, Osyp. "Rozhrom molodoi literatury v Ukraini." Smoloskyp, vol. 15, no. 4, July-Aug. 1963, pp. 2-5. Available on-line: http://diasporiana.org.ua/wpcontent/uploads/books/12698/file.pdf. Accessed 19 Jan. 2020.

Zolotonosov, Mikhail. "Kak pisateli borolis' s p'ianstvom, i chto iz etogo vyshlo." 812 Online, 30 Dec. 2010. http://www.online812.ru/2010/12/29/003/. Accessed 14 Sept. 2019. 
Archives

CIA (Central Intelligence Agency) Archive. Special Collection "The Caesar, Polo, and ESAU Papers." Office of Current Intelligence. "The Soviet Writer and Soviet Cultural Policy," 15 Sept. 1959. Declassified: June 2007. Available at https://www.cia.gov/library/readingroom/document/5077054e993247d4d8 2b6ac0, pp. i-49. Accessed 11 Jan. 2020.

---. Collection "Nazi War Crimes Disclosure Act." "A New Freeze (A Collection of Material on Recent Developments in Ukrainian Soviet Literature)," 28 Aug. 1963. Declassified: $2007 . \quad$ Available at https://www.cia.gov/library/readingroom/docs/AERODYNAMIC $\% 20 \% 20 \% 2$ OVOL.\%2026\%20\%20\%280PERATIONS\%29_0071.pdf, pp. 1-49. Accessed 11 Jan. 2020.

DAKh0, the State Archive of Kharkiv Oblast (Derzhavnyi arkhiv Kharkivs'koi oblasti). Fond R-6165. The Kharkiv Chapter of the Writers' Union (Kharkivs'ke viddilennia Spilky Pys'mennykiv Ukrainy).

HDA SBU, the Sectoral State Archive of the Security Service in Ukraine (Haluzevyi derzhavnyi arkhiv Sluzhby Bezpeky Ukrainy). Fond 16. The Secretariat of the GPU-KGB of the URSR.

Lidiia Tret'iakova's Private Archive (LTPA). Lidiia Tret'iakova's Diary, 30 March, 1957 entry.

TsDAHOU, the Central State Archive of Civic Organizations in Ukraine (Tsentral'nyi Derzhavnyi Arkhiv Hromads'kykh Ob"'iednan' Ukrainy). Fond 1. The Central Committee of the Communist Party of Ukraine.

TsDAMLIMU, the Central State Archive-Museum of Literature and Art of Ukraine (Tsentral'nyi derzhavnyi arkhiv-muzei literatury i mystetstva Ukrainy). Fond 783: Iurii Shovkoplias; Fond 781: Radii Polons'kyi.

Interviews

Boltryk, Serhii. 11 Nov. 1996. Kharkiv. Interview conducted in Russian.

Briuhhen, Volodymyr. 2 July 2011; 27 July 2011; 16 July 2015. Kharkiv. Interviews conducted in Ukrainian.

Buidin, Gennadii. 18 Dec. 2018. Kharkiv. Interview conducted in Russian.

Ievtushenko, Ievgenii. 16 May 1988. Kharkiv. Interview conducted in Russian.

Kasha, Aleksandr. 5 July 1985. Kharkiv. Interview conducted in Russian.

Marchenko, Oleksa. 19 July 2004. Kharkiv. Interview conducted in Ukrainian.

Mykhailyn, Ihor. 13 May 2015. Kharkiv. Interview conducted in Ukrainian.

Pererva, Anatolii. 17 July 2017. Kharkiv. Interviews conducted in Ukrainian.

Polons'kyi, Radii. 16 May 1988. Kharkiv. Interviews conducted in Ukrainian.

Starodub, Anatolii. 12 Aug. 2008. Kharkiv. Interviews conducted in Ukrainian.

Tret'iakova, Lidiia. 19 July 2005. Kharkiv. Interview conducted in Russian.

Tret'iakov, Robert. 2 July 1986; 17 June 1996. Kharkiv. Interviews conducted in Ukrainian. 


\section{Private correspondence}

Briuhhen, Volodymyr. 2010-2018. Correspondence via regular mail. Kharkiv, Ukraine-Bloomsburg, PA, USA

Brusilovskii, Anatolii. 1 Sept. 2017. Email correspondence.

Hundorova, Tamara. 29 July 2016. Email correspondence.

Muratova, Ol'ha. 13 Aug. 2017. Messenger (FB) correspondence. 